\title{
Groundwater salinization processes and reversibility of seawater intrusion in coastal carbonate aquifers
}

\author{
Dongmei Han ${ }^{\mathrm{a}, \mathrm{b}, *}$, Vincent E.A. Post ${ }^{\mathrm{b}}$, Xianfang Song ${ }^{\mathrm{a}}$ \\ ${ }^{a}$ Key Laboratory of Water Cycle E Related Land Surface Processes, Institute of Geographic Sciences and Natural Resources Research, Chinese Academy of Sciences, Beijing \\ 100101, China \\ ${ }^{\mathrm{b}}$ School of the Environment/National Centre for Groundwater Research E' Training, Flinders University, GPO Box 2100, Adelaide, SA 5001, Australia
}

\section{A R T I C L E I N F O}

\section{Article history:}

Received 26 March 2015

Received in revised form 23 October 2015

Accepted 7 November 2015

Available online 19 November 2015

This manuscript was handled by Peter K. Kitanidis, Editor-in-Chief, with the assistance of Massimo Rolle, Associate Editor

\section{Keywords:}

Carbonate aquifer

Seawater intrusion

Groundwater hydrochemistry

Hydrogeochemical modeling

China

\begin{abstract}
S U M M A R Y
Seawater intrusion (SWI) has led to salinization of fresh groundwater reserves in coastal areas worldwide and has forced the closure of water supply wells. There is a paucity of well-documented studies that report on the reversal of SWI after the closure of a well field. This study presents data from the coastal carbonate aquifer in northeast China, where large-scale extraction has ceased since 2001 after salinization of the main well field. The physical flow and concomitant hydrogeochemical processes were investigated by analyzing water level and geochemical data, including major ion chemistry and stable water isotope data. Seasonal water table and salinity fluctuations, as well as changes of $\delta^{2} \mathrm{H}-\delta^{18} \mathrm{O}$ values of groundwater between the wet and dry season, suggest local meteoric recharge with a pronounced seasonal regime. Historical monitoring testifies of the reversibility of SWI in the carbonate aquifer, as evidenced by a decrease of the $\mathrm{Cl}^{-}$concentrations in groundwater following restrictions on groundwater abstraction. This is attributed to the rapid flushing in this system where flow occurs preferentially along karst conduits, fractures and fault zones. The partially positive correlation between $\delta^{18} \mathrm{O}$ values and TDS concentrations of groundwater, as well as high $\mathrm{NO}_{3}^{-}$concentrations ( $>39 \mathrm{mg} / \mathrm{L}$ ), suggest that irrigation return flow is a significant recharge component. Therefore, the present-day elevated salinities are more likely due to agricultural activities rather than SWI. Nevertheless, seawater mixing with fresh groundwater cannot be ruled out in particular where formerly intruded seawater may still reside in immobile zones of the carbonate aquifer. The massive expansion of fish farming in seawater ponds in the coastal zone poses a new risk of salinization. Cation exchange, carbonate dissolution, and fertilizer application are the dominant processes further modifying the groundwater composition, which is investigated quantitatively using hydrogeochemical models.
\end{abstract}

(C) 2015 Elsevier B.V. All rights reserved.

\section{Introduction}

Increased groundwater exploitation to meet the ever-growing fresh water demands has resulted in seawater intrusion (SWI) in coastal aquifers around the world. Karst terrains cover roughly one-tenth of the earth's continents (Drew, 1999) and groundwater from karst aquifers contributes significantly to the water demand in many coastal regions. Due to their importance, coastal karst aquifers have been extensively studied in, for example, America (Fleury et al., 2007), Spain (Martinez-Santos et al., 2005), Morocco

\footnotetext{
* Corresponding author at: Key Laboratory of Water Cycle \& Related Land Surface Processes, Institute of Geographic Sciences and Natural Resources Research, Chinese Academy of Sciences, Beijing 100101, China. Tel.: +86 10 64888866; fax: +86 10 64889849.

E-mail addresses: handm@igsnrr.ac.cn, dmeihan@gmail.com (D. Han).
}

(Bouchaou et al., 2008; El Yaouti et al., 2009), Mexico (Escolero et al., 2007), Israel (Kafri et al., 2007), Greece (Panagopoulos, 2008), and Croatia (Biondić et al., 2006). Well-documented case studies published in the literature are mostly from limestone and dolomite aquifers of Mesozoic to Cenozoic age, e.g. along the Mediterranean coast (Magaritz et al., 1984; Fidelibus et al., 1993), the Caribbean coast (Plummer, 1977; Back et al., 1979; Scott et al., 2002), and the Atlantic coast (Renken et al., 2002). These rocks were subjected to intense karstification that reached several hundred meters deep (Cita and Ryan, 1978; Bicalho et al., 2012), and may have high secondary (i.e. formed postdeposition) permeability (White, 2003). The resulting permeability distribution is thereby different from Paleozoic limestones and dolomites, which typically have very low secondary permeability (White, 2003). Apart from a few Chinese studies (e.g., Fan, 1984; Wu et al., 1994), it would appear that no studies have focused on 
salt water intrusion in these older systems, of which the coastal karst systems in northeastern China form an example. They developed in carbonate rocks of Ordovician and Cambrian age (Li et al., 2006), and it may be expected that their low permeability causes SWI to occur preferentially along faults and fracture zones.

Moreover, the dual-porosity nature of such mediums may have an impact on the reversibility of SWI, as seawater may enter the stagnant zones of the aquifer during stages of SWI, which then becomes slowly released by diffusive mass transfer after the more mobile parts of the aquifer have been freshened. Studies that document the reversal of seawater intrusion are quite rare in the literature and mainly constrained to technical reports. SWI reversibility has been identified in the Biscayne Aquifer near a well field in Broward County in Florida, USA (Dunn, 2000). There a seaward movement of the freshwater interface was recorded during a period of declined abstraction between 1979 and 1994, and a lag time was observed between the rise of water levels in the aquifer and measured salinities. The lag time ranged from 1.5 to 4.5 years in the wells analyzed and it was found to increase with decreasing permeability and increasing distance from the coast (Dunn, 2000). A seasonal dependence of SWI has also been reported for limestone aquifers in the Mediterranean region and in England (Giordana and Montginoul, 2006). A review of selected cases by these authors showed that the aquifer permeability and recharge rates form the dominant controls on the timescale of SWI reversibility. Giordana and Montginoul (2006) further found that in some sedimentary aquifers salinization by SWI persisted, leading to exploitation of groundwater of a lower quality.

This study reports on the coastal carbonate aquifer of Dalian region, where groundwater salinization occurred as early as 1964. Most of the previous research efforts in the study area have focused on identifying the extent of salinization near the Daweijia well field, which formed one of the largest groundwater sources for Dalian City before 2001 (Fan, 1984; Wu et al., 1994; Zou et al., 2001,2004 ). The increase in groundwater salinity has been attributed to SWI caused by over-abstraction (Lü et al., 1981). However, relatively subtle increases in groundwater salinity in coastal aquifers like those observed in the Dalian area are not always due to SWI, and it cannot be excluded that the increase of groundwater salinity was not only caused by SWI, but also by human activities (e.g. agricultural irrigation, fish farming) and droughts.

To determine groundwater salinization sources and processes, and assess SWI reversibility, salinity and water level data from previous studies have been synthesized, and were complemented by newer chemical and isotope data collected after closure of the well field in 2001. Major ion concentrations combined with isotope data have successfully been used for this purpose in other studies (e.g., Vengosh and Rosenthal, 1994; Edmunds, 1996; Vengosh et al., 1999; Daniele et al., 2013). These data can also be used to understand the water-rock interaction processes associated with mixing, such as mineral dissolution/precipitation and ion exchange (Wigley and Plummer, 1976; Back et al., 1979; Nadler, 1980; Hanshaw and Back, 1985; Sanford and Konikow, 1989; Fidelibus and Tulipano, 1991; Stuyfzand, 2008).

This study is the first to comprehensively characterize the groundwater flow system in the coastal carbonate aquifers in northeastern China. The Dalian area provides an interesting case study as salinization became so severe that the Daweijia well field was forced to shut down in 2001. The main objectives were to (i) develop a conceptual model of the groundwater system of the Dalian region as an exemplar of a coastal karst aquifer in carbonate rocks of low permeability, (ii) understand the hydrochemical and hydrodynamic conditions after closure of the Daweijia well field, and (iii) document the temporal changes of the extent of SWI.

\section{Study area}

Dalian is located in the southern tip of Liaodong Peninsula, and is one of the most important industrial regions in China. The study area is located between $121^{\circ} 37^{\prime}$ to $121^{\circ} 44^{\prime}$ east and $39^{\circ} 10^{\prime}$ to $39^{\circ} 14^{\prime}$ north, and has an area of approximately $66 \mathrm{~km}^{2}$ (Fig. 1). It is centered around the Daweijia well field of Dalian City, in the Liaoning Province in northeastern China. Elevation ranges from $121 \mathrm{~m}$ above sea level (m.a.s.l.) in the north, 140 m.a.s.l. in the east, and 320 m.a.s.l. in the south, to 1-2 m.a.s.l. at the coast in the west.

The area is characterized by a temperate semi-humid monsoon climate. The mean annual air temperature is $10.5^{\circ} \mathrm{C}$, mean annual rainfall (averaged from 1956 to 2000) is $613 \mathrm{~mm}$ (Li, 2004) and mean annual potential evaporation is $1548 \mathrm{~mm}$ (Yang, 2011). As much as $60-70 \%$ of the annual precipitation falls between June and September. The Daweijia River has a length of $15.5 \mathrm{~km}$, and originates in the eastern part of the study area (Fig. 1). It has an annual average discharge of approximately $14 \times 106 \mathrm{~m}^{3} /$ year (Li, 2004), and has a seasonal flow regime.

Geologically, the area is part of an opening basin facing the Bohai Sea (Wu and Jin, 1990). The strata outcropping in the Daweijia area include Ediacaran argillaceous limestone, shale, slate and metamorphic rocks, Cambrian-Ordovician limestone and dolomitic limestone, Cambrian sandstone and shale, and Holocene and Pleistocene sediments (Fig. 1). The composition of strata is given in Table 1. The Cenozoic sediments in the Daweijia area are mostly underlain by the Cambrian-Ordovician limestone in the south and east and Cambrian sandstone and shale in the north.

The tectonic structures of the study area are well developed with faults and folds in various directions. There are two groups of faults developed in this area, including a NE-SW group (F1 and F2 in Fig. 1) and an E-W group (F3 and F4 in Fig. 1). Generally, karst development becomes less with depth, transitioning from caves at shallower depth to fissures in deeper parts (Li et al., 2006). Although the karst is well-developed in the upper carbonate rocks ( 0 to -40 m.a.s.l.), the presence of clay-rich sediments in this depth range can restrict water circulation (Zhao, 1991). The main aquifers in the study area are composed of pure and thicklybedded limestone and dolomitic limestone in the lower Ordovician and upper-middle Cambrian sections between -40 and -70 m.a.s.l (Lü et al., 1981; Zhao, 1991). Karst here is less-developed than at shallower depths, but the absence of clay results in better hydrodynamic conditions (Zhao, 1991). The most productive carbonate aquifers are located in the valley along Daweijia River.

A Quaternary aquifer of 10-40 m thick sits on top of the carbonate aquifers, and the two aquifers are hydraulically connected (Jin and Wu, 1990). The Quaternary aquifer is mainly composed of alluvium and marine sand and gravel layers. The alluvium deposits are mainly distributed along the valley of Daweijia River, and are composed of sandy loam with a thickness of $2-10 \mathrm{~m}$ in the upper part, and sandy gravel with a thickness of $5-20 \mathrm{~m}$ in the lower part (Lü et al., 1981). The main composition of these deposits is quartz sandstone and limestone. Near the coast, the carbonate aquifer becomes semi-confined, and separated from the overlying Quaternary aquifer, by an up to $10 \mathrm{~m}$ thick marine clay layer (Lü et al., 1981). The marine clay layer has a thickness varying from $2 \mathrm{~m}$ inland to $10 \mathrm{~m}$ at coast within $3.5 \mathrm{~km}$ away from the coast (Lü et al., 1981).

The Daweijia well field is located near the fault zone and provided water to Dalian City. Pumping occurred at 3 locations from a total of 5 wells ( 2 at CG2, 2 at CG3, 1 near QG9, Fig. 1) with depths (bottom of the screen) ranging between 90 and $128 \mathrm{~m}$ (Lü et al., 1981). The screened intervals of these wells are mainly from 70 to $120 \mathrm{~m}$ depth below ground surface. During the periods of intensive withdrawal (1977-1984) groundwater salinity rose and water 


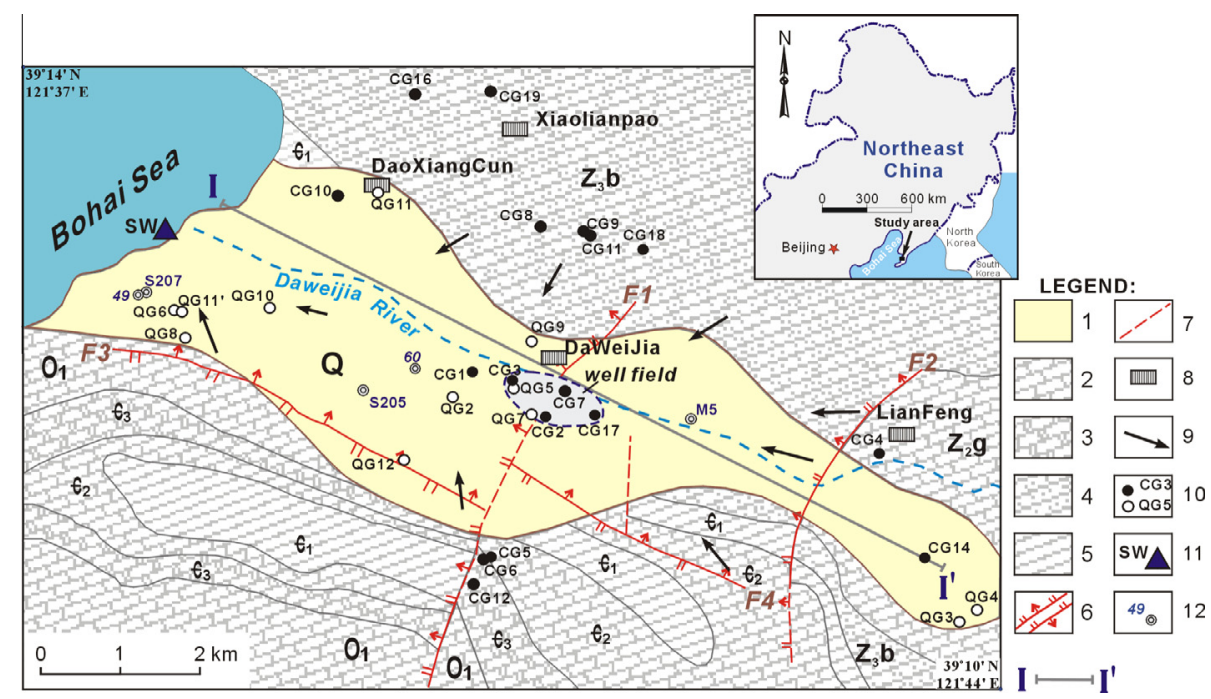

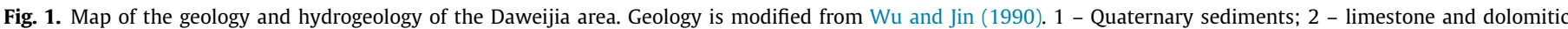

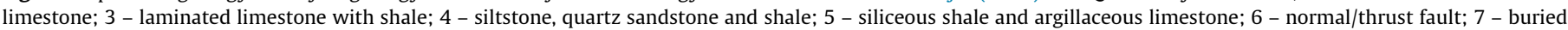

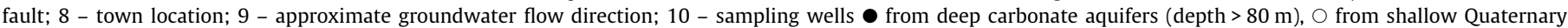

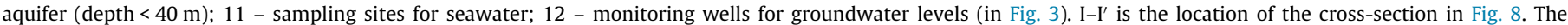
description of the outcropping strata (marked $\mathrm{Q}, \mathrm{O}_{1}, \epsilon_{3}, \epsilon_{2}, \epsilon_{1}, Z_{3} \mathrm{~b}, \mathrm{Z}_{2} \mathrm{~g}$ ) is listed in Table 1 .

Table 1

Hydrogeology of the Daweijia area (from Liu et al., 1982).

\begin{tabular}{|c|c|c|c|c|c|}
\hline Erathem Era & $\begin{array}{l}\text { System } \\
\text { period }\end{array}$ & & Serious Epoch & $\begin{array}{l}\text { Stratigraphic } \\
\text { thickness (m) }\end{array}$ & Lithology description \\
\hline \multirow[t]{4}{*}{ Cenozoic } & \multirow[t]{4}{*}{ Quaternary (Q) } & Holocene & & $5-60$ & Marine sand and gravel, mucky silt \\
\hline & & Pleistocene & Upper & & Pluvial and alluvial sand loam, sand and gravel \\
\hline & & & Middle & & $\begin{array}{l}\text { Deluvium and pluvial sand loam, sand and gravel with gravel } \\
\text { lenses }\end{array}$ \\
\hline & & & Lower & & Clay gravel, glacial depositions \\
\hline \multirow[t]{4}{*}{ Paleozoic } & Ordovician & Middle-Lower $\left(\mathrm{O}_{1-2}\right)$ & & 460 & $\begin{array}{l}\text { Gray thick-beded limestone, dolomitic limestone with chert } \\
\text { nodules, bamboo-like limestone }\end{array}$ \\
\hline & Cambrian & Upper $\left(\epsilon_{3}\right)$ & & 235 & Laminated limestone with shale \\
\hline & & Middle $\left(\epsilon_{2}\right)$ & & 305 & $\begin{array}{l}\text { Thick-beded limestone interbeded by argillaceous limestone, } \\
\text { shale on the bottom }\end{array}$ \\
\hline & & Lower $\left(\epsilon_{1}\right)$ & & 517 & $\begin{array}{l}\text { Sandstone, siliceous shale, argillaceous limestone with weak } \\
\text { permeability }\end{array}$ \\
\hline \multirow[t]{8}{*}{ Proterozoic } & \multirow[t]{8}{*}{ Ediacaran } & \multirow[t]{3}{*}{ Upper } & Beishan group $\left(\mathrm{Z}_{3} \mathrm{~b}\right)$ & 187 & Siltstone, quart sandstone, shale and slabstone \\
\hline & & & Majiashan group $\left(\mathrm{Z}_{3} \mathrm{~m}\right)$ & 150 & Banded argillaceous limestone \\
\hline & & & Shisanlitai group $\left(\mathrm{Z}_{3} \mathrm{~s}\right)$ & 195 & Thick-beded limestone, shale \\
\hline & & \multirow[t]{4}{*}{ Middle } & $\begin{array}{l}\text { Yingchengzi group } \\
\left(\mathrm{Z}_{2} \mathrm{y}\right)\end{array}$ & 455 & Medium-thick-beded pure limestone with argillaceous limestone \\
\hline & & & Ganjingzi group $\left(Z_{2} g\right)$ & 671 & $\begin{array}{l}\text { Medium-thick-beded limestone with chert and siliceous } \\
\text { dolomitic limestone }\end{array}$ \\
\hline & & & $\begin{array}{l}\text { Nanguanling group } \\
\left(\mathrm{Z}_{2} \mathrm{n}\right)\end{array}$ & 770 & $\begin{array}{l}\text { Medium-thick-beded argillaceous limestone and thick-beded } \\
\text { limestone }\end{array}$ \\
\hline & & & Changlingzi group $\left(\mathrm{Z}_{2} \mathrm{c}\right)$ & 1357 & $\begin{array}{l}\text { Calcareous slate, argillaceous limestone with banded fine-grained } \\
\text { sandstone }\end{array}$ \\
\hline & & Lower & Chagou group $\left(Z_{1} c\right)$ & 10,000 & Quartzite, quartz sandstone, calcareous and siliceous slate \\
\hline
\end{tabular}

level fluctuated significantly (Wu et al., 1994, see Supplementary Fig. S1), and consequently many wells were abandoned. Pumping rates increased from a rate of 1.2 to $2.4 \times 104 \mathrm{~m}^{3} / \mathrm{d}$ in 1970 to a rate of 4.8 to $6.2 \times 104 \mathrm{~m}^{3} / \mathrm{d}$ in 1977 (Lü et al., 1981). Later then the pumping rate was still increasing till 1983. In 1983, the abstraction from the Daweijia well field was changed from a perennial withdrawal of groundwater to a seasonal regime, along with a reduction by two-thirds of the pumped volume. The exploitation increased after 1991 but was reduced again from $2 \times 104 \mathrm{~m}^{3} / \mathrm{d}$ in 1995 to $0.4 \times 104 \mathrm{~m}^{3} / \mathrm{d}$ in 2000 (Li et al., 2006). Since 2001, apart from seasonal pumping for local agricultural irrigation, water supply for Dalian City from the well field has ceased (Song, 2013), and the government has established surface water supply projects as an alternative. Presently, groundwater supply for agricultural purposes is mainly from pumping wells CG2, CG3, CG7, and CG17 (Fig. 1) with screened intervals in the carbonate aquifer. The Quaternary aquifer remains in a state of over-exploitation due to widespread pumping for agricultural purposes.

The main sources of groundwater recharge are rainfall and the lateral subsurface inflow from the surrounding hills (Fan, 1984). The Daweijia River is the source of some recharge during the rainy season. Before the 1960s, there were many karst springs in the rainy season, which were the main discharge pathways in this area (Liu et al., 1982; Zhao, 1991). Nowadays, pumping from domestic 
Sample locations, depths, major hydrochemical and isotopic composition in the investigated waters (results from 2008, 2009 and 2010 sampling campaigns).

\begin{tabular}{|c|c|c|c|c|c|c|c|c|c|c|c|c|c|c|c|c|c|c|c|}
\hline Well & $\begin{array}{l}\text { Sampling } \\
\text { time }\end{array}$ & $\begin{array}{l}\text { Well depth } \\
\text { (m) }\end{array}$ & $\begin{array}{l}\text { Screen interval } \\
(\mathrm{m})\end{array}$ & $\begin{array}{l}\mathrm{EC}(\mathrm{mS} / \\
\mathrm{cm})\end{array}$ & $\mathrm{pH}$ & $\begin{array}{l}T \\
\left({ }^{\circ} \mathrm{C}\right)\end{array}$ & $\begin{array}{l}\mathrm{DO} \\
(\mathrm{mg} / \mathrm{L})\end{array}$ & $\begin{array}{l}\mathrm{Ca}^{2+} \\
(\mathrm{mg} / \mathrm{L})\end{array}$ & $\begin{array}{l}\mathrm{Mg}^{2+} \\
(\mathrm{mg} / \mathrm{L})\end{array}$ & $\begin{array}{l}\mathrm{Na}^{+} \\
(\mathrm{mg} / \mathrm{L})\end{array}$ & $\begin{array}{l}\mathrm{K}^{+} \\
(\mathrm{mg} / \mathrm{L})\end{array}$ & $\begin{array}{l}\mathrm{Cl}^{-} \\
(\mathrm{mg} / \mathrm{L})\end{array}$ & $\begin{array}{l}\mathrm{NO}_{3}^{-} \\
(\mathrm{mg} / \mathrm{L})\end{array}$ & $\begin{array}{l}\mathrm{SO}_{4}^{2-} \\
(\mathrm{mg} / \mathrm{L})\end{array}$ & $\begin{array}{l}\mathrm{HCO}_{3}^{-} \\
(\mathrm{mg} / \mathrm{L})\end{array}$ & $\begin{array}{l}\text { CBE } \\
(\%)\end{array}$ & $\begin{array}{l}\text { TDS } \\
(\mathrm{mg} / \mathrm{L})\end{array}$ & $\begin{array}{l}\delta \mathrm{D} \\
(\%)\end{array}$ & $\begin{array}{l}\delta^{18} \mathrm{O} \\
(\%)\end{array}$ \\
\hline \multicolumn{20}{|c|}{ Investigated groundwater from Carbonate aquifers } \\
\hline CG3 & Jun. 2008 & 110 & $72-98$ & 1.33 & 7.74 & 13.6 & & 110.6 & 35.5 & 66.1 & 1.3 & 230.0 & 57.0 & 89.7 & 167.4 & -3.6 & 673.8 & -57 & -6.0 \\
\hline CG4 & Jun. 2008 & 100 & $70-95$ & 0.94 & 7.59 & 14.5 & & 86.6 & 30.5 & 33.8 & 0.8 & 124.6 & 47.5 & 69.5 & 172.9 & -1.8 & 479.7 & -54 & -7.3 \\
\hline CG8 & Jun. 2008 & 95 & $65-92$ & 1.33 & 7.84 & 20.5 & & 140.9 & 28.0 & 52.2 & 1.0 & 130.8 & 312.0 & 74.6 & 124.9 & -3.4 & 801.9 & -57 & -6.6 \\
\hline CG11 & Jun. 2008 & 100 & $67-93$ & 1.25 & 7.51 & 14.8 & & 120.3 & 22.5 & 63.8 & 2.4 & 169.7 & 69.6 & 85.0 & 197.6 & -1.7 & 632.1 & -59 & -7.5 \\
\hline CG13 & Jun. 2008 & 100 & $74-92$ & 1.19 & 7.55 & 11.3 & & 126.3 & 31.3 & 42.6 & 3.6 & 117.8 & 104.3 & 143.2 & 189.4 & -1.5 & 663.8 & -54 & -6.5 \\
\hline CG14 & Jun. 2008 & 128 & $85-118$ & 0.68 & 7.92 & 14.5 & & 70.4 & 24.6 & 18.1 & 0.6 & 60.3 & 60.8 & 44.4 & 159.2 & 0.9 & 358.8 & -58 & -7.6 \\
\hline CG3 & Aug. 2009 & 110 & $72-98$ & 1.01 & 7.99 & 14.6 & & 140.6 & 34.0 & 50.2 & 0.9 & 104.4 & 38.6 & 88.5 & 130.9 & 22.4 & 522.6 & -59 & -8.4 \\
\hline CG4 & Aug. 2009 & 100 & 70-95 & 1.03 & 7.94 & 14.8 & & 130.4 & 41.6 & 41.8 & 0.7 & 126.6 & 44.2 & 81.4 & 138.6 & 17.2 & 536.0 & -57 & -8.3 \\
\hline CG5 & Aug. 2009 & 120 & $75-112$ & 0.91 & 7.67 & 13.4 & & 122.7 & 27.3 & 36.7 & 0.9 & 78.6 & 62.8 & 73.9 & 130.9 & 17.8 & 468.3 & -58 & -8.4 \\
\hline CG7 & Aug. 2009 & 92 & $59-88$ & 1.62 & 8.34 & 14.4 & & 192.1 & 45.8 & 95.8 & 0.6 & 238.1 & 243.6 & 121.2 & 100.1 & 7.7 & 987.3 & -54 & -8.0 \\
\hline CG8 & Aug. 2009 & 95 & $65-92$ & 1.36 & 7.98 & 13.2 & & 196.7 & 28.1 & 65.7 & 0.5 & 168.3 & 258.5 & 69.0 & 107.8 & 10.1 & 840.8 & -54 & -8.2 \\
\hline CG10 & Aug. 2009 & 90 & $59-86$ & 1.51 & 8.11 & 18.8 & & 192.7 & 36.7 & 80.2 & 1.0 & 191.5 & 236.5 & 84.8 & 100.1 & 11.6 & 873.4 & -58 & -7.8 \\
\hline CG12 & Aug. 2009 & 100 & $68-93$ & 1.28 & 8.09 & 19.8 & & 185.8 & 27.6 & 71.8 & 1.2 & 178.4 & 69.1 & 105.0 & 154.0 & 14.4 & 715.9 & -58 & -8.0 \\
\hline CG14 & Aug. 2009 & 128 & $85-118$ & & 8.26 & 12.7 & & 105.4 & 32.4 & 23.8 & 0.2 & 55.7 & 62.5 & 46.1 & 123.2 & 23.3 & 387.7 & -57 & -8.2 \\
\hline CG17 & Aug. 2009 & 110 & $68-97$ & 1.32 & 8.67 & 14.5 & & 147.6 & 35.3 & 78.7 & 1.0 & 165.9 & 228.5 & 54.7 & 84.7 & 10.7 & 754.1 & -57 & -7.9 \\
\hline CG18 & Aug. 2009 & 70 & $55-68$ & 1.14 & 8.35 & 13.2 & & 184.9 & 24.7 & 31.3 & 0.3 & 72.2 & 327.9 & 77.1 & 84.7 & 9.8 & 760.6 & -57 & -8.0 \\
\hline CG4 & Aug. 2010 & 100 & $70-95$ & 1.02 & 7.23 & 16.1 & 3.64 & 119.6 & 38.5 & 50.5 & 1.2 & 136.8 & 60.9 & 109.7 & 247.1 & 0.8 & 640.8 & -59 & -8.2 \\
\hline CG16 & Aug. 2010 & 88 & $58-84$ & 0.72 & 7.53 & 22.4 & 5.65 & 100.9 & 16.1 & 26.1 & 4.7 & 112.1 & 77.2 & 82.4 & 101.2 & -1.0 & 470.2 & -55 & -8.1 \\
\hline CG3 & Aug. 2010 & 110 & $72-98$ & 0.99 & 7.31 & 19.3 & 4.01 & 115.8 & 37.8 & 47.2 & 1.5 & 128.7 & 60.3 & 93.8 & 282.8 & -1.0 & 626.5 & -57 & -8.4 \\
\hline CG6 & Aug. 2010 & 120 & $75-112$ & 0.80 & 7.32 & 21.7 & 3.67 & 99.4 & 24.1 & 38.2 & 1.2 & 88.0 & 43.1 & 67.1 & 250.1 & -0.2 & 486.1 & -59 & -8.5 \\
\hline CG14 & Aug. 2010 & 128 & $85-118$ & 0.75 & 7.57 & 22.0 & 7.20 & 94.5 & 31.9 & 24.5 & 1.0 & 71.1 & 69.1 & 65.1 & 238.1 & 0.3 & 476.2 & -59 & -8.4 \\
\hline CG9 & Aug. 2010 & 100 & $68-92$ & 0.85 & 7.56 & 18.8 & 8.63 & 113.6 & 17.4 & 44.4 & 6.5 & 79.3 & 147.9 & 101.8 & 134.0 & 1.4 & 577.9 & -65 & -10.0 \\
\hline CG2 & Jun. 2008 & 120 & $72-107$ & 2.04 & 7.44 & 13.8 & & 188.3 & 47.9 & 93.4 & 1.8 & 288.9 & 325.9 & 125.9 & 145.5 & -3.3 & 1144.8 & -52 & -7.0 \\
\hline CG7 & Jun. 2008 & 92 & $59-88$ & 2.06 & 7.27 & 13.8 & & 182.8 & 49.1 & 88.1 & 1.4 & 311.6 & 366.0 & 144.4 & 96.1 & -6.8 & 1191.4 & -56 & -7.0 \\
\hline CG9 & Jun. 2008 & 100 & $68-92$ & 2.25 & 7.66 & 14.3 & & 260.3 & 39.8 & 91.1 & 3.0 & 289.4 & 561.4 & 130.8 & 151.0 & -5.4 & 1451.2 & -58 & -7.6 \\
\hline CG10 & Jun. 2008 & 90 & $59-86$ & 1.56 & 7.98 & 15.9 & & 174.0 & 36.7 & 65.2 & 2.1 & 336.7 & 186.9 & 228.3 & 131.8 & -14.7 & 1095.8 & -60 & -7.6 \\
\hline CG1 & Jun. 2008 & 100 & $71-93$ & 2.15 & 7.12 & 12.6 & & 164.2 & 60.2 & 162.5 & 3.3 & 570.9 & 234.6 & 130.1 & 200.4 & -13.1 & 1425.9 & -54 & -6.8 \\
\hline CG2 & Aug. 2009 & 120 & $72-107$ & 1.80 & 8.65 & 13.9 & & 209.4 & 49.8 & 115.0 & 1.5 & 284.2 & 296.7 & 116.4 & 100.1 & 6.7 & 1123.0 & -56 & -8.0 \\
\hline CG9 & Aug. 2009 & 100 & $68-92$ & 2.00 & 7.89 & 13.5 & & 297.6 & 40.1 & 79.2 & 1.7 & 174.2 & 510.4 & 145.0 & 107.8 & 9.0 & 1302.1 & -58 & -7.9 \\
\hline CG1 & Aug. 2009 & 100 & $71-93$ & 2.44 & 8.41 & 15.5 & & 221.8 & 72.5 & 189.7 & 2.7 & 484.1 & 225.1 & 121.2 & 146.3 & 5.6 & 1390.3 & -58 & -7.7 \\
\hline CG19 & Aug. 2009 & 62 & $43-59$ & 1.78 & 7.69 & 13.2 & & 198.3 & 66.8 & 70.7 & 1.8 & 152.3 & 296.1 & 172.3 & 207.9 & 6.7 & 1062.3 & -56 & -8.1 \\
\hline CG2 & Aug. 2010 & 120 & $72-107$ & 2.05 & 6.49 & 16.0 & 7.49 & 187.7 & 48.5 & 106.0 & 2.3 & 258.4 & 263.9 & 189.2 & 199.4 & -2.0 & 1155.7 & -59 & -8.2 \\
\hline CG7 & Aug. 2010 & 92 & $59-88$ & 1.76 & 6.56 & 17.0 & 6.56 & 198.5 & 51.1 & 97.8 & 1.0 & 255.3 & 334.7 & 240.5 & 145.9 & -4.2 & 1251.9 & -58 & -8.1 \\
\hline CG17 & Aug. 2010 & 110 & $68-97$ & 1.37 & 6.95 & 14.2 & 6.96 & 149.1 & 38.3 & 82.9 & 1.5 & 197.4 & 278.8 & 134.1 & 163.7 & -4.4 & 963.9 & -58 & -8.1 \\
\hline CG1 & Aug. 2010 & 100 & 71-93 & 2.28 & 7.15 & 18.2 & 5.64 & 212.5 & 72.3 & 184.0 & 3.5 & 445.6 & 282.6 & 201.4 & 282.8 & -2.6 & 1543.3 & -57 & -7.9 \\
\hline CG8 & Aug. 2010 & 95 & $65-92$ & 1.42 & 7.39 & 20.0 & 6.11 & 190.6 & 32.1 & 66.7 & 1.4 & 177.1 & 256.6 & 104.1 & 190.5 & 2.3 & 923.8 & -57 & -8.2 \\
\hline CG11 & Aug. 2010 & 100 & $67-93$ & 2.05 & 7.07 & 15.1 & 7.60 & 302.8 & 42.3 & 84.3 & 1.7 & 223.3 & 579.4 & 249.9 & 205.4 & -4.1 & 1586.4 & -57 & -8.3 \\
\hline CG12 & Aug. 2010 & 100 & $68-93$ & 1.36 & 7.34 & 20.0 & 7.41 & 183.0 & 31.9 & 81.3 & 1.6 & 208.7 & 90.1 & 146.2 & 318.5 & -0.9 & 902.0 & -59 & -8.3 \\
\hline CG19 & Aug. 2010 & 62 & $43-59$ & 1.48 & 6.72 & 14.5 & 4.71 & 220.0 & 72.1 & 70.6 & 2.0 & 136.0 & 265.6 & 219.1 & 446.5 & 0.1 & 1208.6 & -57 & -8.3 \\
\hline CG10 & Aug. 2010 & 90 & $59-86$ & 1.59 & 7.35 & 21.5 & 7.35 & 207.7 & 42.4 & 62.0 & 26.4 & 168.9 & 295.7 & 306.9 & 205.4 & -5.7 & 1212.7 & -57 & -8.0 \\
\hline \multicolumn{20}{|c|}{ Investigated groundwater from Quaternary aquifers } \\
\hline QG4 & Jun. 2008 & 14 & $7-13$ & 0.80 & 7.75 & 12.7 & & 76.3 & 22.1 & 25.8 & 6.1 & 62.5 & 109.1 & 85.0 & 126.3 & -3.0 & 450.1 & -50 & -6.8 \\
\hline QG3 & Jun. 2008 & 8.4 & $6-7.5$ & 0.56 & 7.8 & 13.1 & & 65.2 & 11.9 & 18.8 & 3.4 & 33.7 & 47.1 & 65.6 & 126.3 & -0.1 & 308.8 & -55 & -7.2 \\
\hline QG9 & Jun. 2008 & 20 & $12-17$ & 1.16 & 7.5 & 14.9 & & 92.1 & 35.8 & 65.3 & 3.6 & 129.9 & 133.7 & 166.9 & 112.5 & -3.7 & 683.6 & -57 & -7.4 \\
\hline QG13 & Jun. 2008 & 11 & $6-10$ & 1.74 & 7.63 & 13.6 & & 171.6 & 32.4 & 80.5 & 1.7 & 272.6 & 230.0 & 97.1 & 118.0 & -2.6 & 944.8 & -54 & -7.4 \\
\hline QG4 & Aug. 2009 & 14 & $7-13$ & & 7.64 & 18.2 & & 130.3 & 42.3 & 51.6 & 8.4 & 66.7 & 121.6 & 131.2 & 130.9 & 17.6 & 617.5 & -57 & -8.1 \\
\hline QG3 & Aug. 2009 & 8.4 & $6-7.5$ & & 7.84 & 16.7 & & 142.7 & 24.3 & 30.6 & 3.3 & 48.2 & 123.0 & 125.3 & 92.4 & 16.9 & 543.5 & -55 & -7.5 \\
\hline QG6 & Aug. 2009 & 14 & $8-13$ & 1.81 & 7.85 & 14.5 & & 173.9 & 51.6 & 147.0 & 2.0 & 128.7 & 193.2 & 121.3 & 138.6 & 24.3 & 887.0 & -57 & -8.0 \\
\hline QG13 & Aug. 2009 & 11 & $6-10$ & 1.48 & 8.12 & 20.8 & & 239.6 & 29.4 & 58.6 & 3.5 & 128.9 & 282.5 & 128.9 & 130.9 & 13.0 & 936.7 & -57 & -8.1 \\
\hline QG7 & Aug. 2010 & 28 & $15-24$ & 1.24 & 7.60 & 13.1 & 6.74 & 156.2 & 27.5 & 82.1 & 1.0 & 254.5 & 146.6 & 54.4 & 262.0 & -5.4 & 853.4 & -52 & -7.3 \\
\hline QG3 & Aug. 2010 & 8.4 & $6-7.5$ & 0.82 & 6.96 & 18.3 & 4.36 & 118.3 & 21.6 & 28.6 & 4.0 & 103.3 & 74.7 & 135.4 & 190.5 & -5.4 & 581.2 & -56 & -8.2 \\
\hline QG4 & Aug. 2010 & 14 & $7-13$ & 0.91 & 7.47 & 23.0 & 3.64 & 99.1 & 40.0 & 42.5 & 13.1 & 69.7 & 80.2 & 145.2 & 241.1 & 0.9 & 610.4 & -58 & -8.6 \\
\hline
\end{tabular}




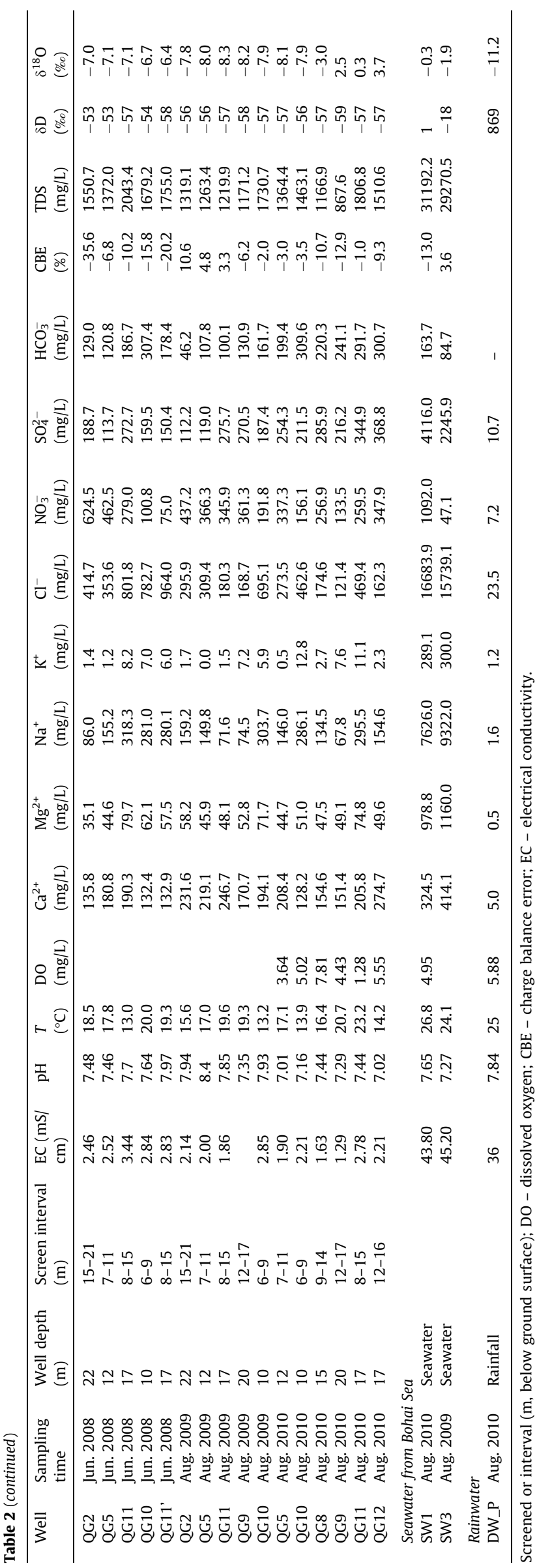

and irrigation wells forms the main discharge pathway, even after the main well field was closed.

Apart from irrigated agriculture in the Daweijia River valley, coastal fish farming, i.e., shellfish (e.g. oyster, scallop, mussel) and shrimp cultivation, has become a major industry over the past four decades (Liu and Liu, 2001; Sun and Shen, 2010). The extensive ponds have led to environmental problems. For example, $80 \%$ of the amount of nitrogen fertilizer input was found to accumulate into the mud at the bottom of shrimp ponds (Sun and Yang, 2011), and thus has become a major pollution source. The seawater from the ponds may also impact on the salinity of groundwater in the underlying aquifers.

\section{Sampling and analysis}

Based on the existing monitoring network by the Chinese Geology Survey, groundwater was collected from 31 groundwater wells ranging from 8.4 to $128 \mathrm{~m}$ depth (appendix Table 2) during three periods from June 2008 to August 2010, along a $9.6 \mathrm{~km}$ transect. The locations of the investigated wells were chosen to be representative for the recharge area, pumping area, and coastal zone. Nineteen of the sampled wells are screened in the Carbonate aquifer, and 12 wells in the Quaternary aquifer (locations are shown in Fig. 1). Two seawater samples were also collected. One rainfall sample was collected on 19 August 2010. Most of the groundwater samples were collected from irrigation and domestic supply wells. The well screen intervals are included in appendix Table 2. It should be noted that the highest contribution of the carbonate aquifer to the well yield is between 72 and $75 \mathrm{~m}$ below ground surface (Jin and $\mathrm{Wu}, 1990)$. Some of the irrigation wells have long screens (even reach $\sim 35 \mathrm{~m}$, see appendix Table 2), and therefore water samples represent a relatively long vertical section of the aquifer. Water table depths below land surface were measured before pumping. $\mathrm{pH}$, temperature, dissolved oxygen (DO) and EC (electrical conductivity) were measured using portable meter (WTW Multi 3500i) in the field. Water samples were taken after constant values of conductivity and redox potential of the pumped water had been reached. Groundwater samples for hydrochemical analysis were filtered in the field using $0.45 \mu \mathrm{m}$ filters, and samples for cation analysis were acidified to $\mathrm{pH}<2$ with

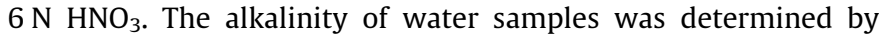
titration with $\mathrm{H}_{2} \mathrm{SO}_{4}(0.22 \mathrm{~N})$ on the day of sample collection. Dissolved oxygen values were determined for the groundwater samples taken in August 2010. All collected samples were stored at $4{ }^{\circ} \mathrm{C}$ in acid-washed polyethylene bottles with watertight caps until analysis.

The hydrochemical composition of all water samples was analyzed at the Physical and Chemical Analysis Laboratory, Institute of Geographic Sciences and Natural Resources Research (IGSNRR), Chinese Academy of Sciences (CAS). The filtered water samples were analyzed for cations $\left(\mathrm{Na}^{+}, \mathrm{K}^{+}, \mathrm{Mg}^{2+}\right.$ and $\left.\mathrm{Ca}^{2+}\right)$ and minor elements ( $\mathrm{Sr}, \mathrm{B}$, and $\mathrm{Si}$ ) by ICP-MS (PerkinElmer, Elan DRC-e). $\mathrm{Cl}^{-}$, $\mathrm{SO}_{4}^{2-}$ and $\mathrm{NO}_{3}^{-}$concentrations were determined by a High Performance Liquid Chromatograph (SHIMADZU, LC-10ADvp). The ion balance errors of the chemical analyses are shown in Table 2. For the chemical calculations, only samples from the 2010 dataset were used. Groundwater samples were divided into three types: fresh, brackish and saline, based on TDS ranges of TDS $<1 \mathrm{~g} / \mathrm{L}$, $1<\mathrm{TDS} \leqslant 10 \mathrm{~g} / \mathrm{L}$ and TDS $>10 \mathrm{~g} / \mathrm{L}$, respectively (Fetter, 1994). The analysis of the stable isotopes of water samples were carried out at the Physical and Chemical Analysis Laboratory, IGSNRR, CAS, with a Finnigan MAT253 after on-line pyrolysis with a Thermo Finnigan TC/EA. Results were expressed relative to the international standards (V-SMOW for ${ }^{18} \mathrm{O}$ and ${ }^{2} \mathrm{H}$ ) expressed in \%. The analytical uncertainties were $\pm 0.3 \%$ o $\delta^{18} \mathrm{O}$ and $\pm 2 \%$ ofor $\delta^{2} \mathrm{H}$. 
The fraction of seawater $\left(f_{\mathrm{sw}}\right)$ was calculated from the $\mathrm{Cl}^{-}$concentration (Appelo and Postma, 2005):

$f_{\mathrm{sw}}=\frac{C_{\mathrm{Cl}, \mathrm{sam}}-C_{\mathrm{Cl}, \mathrm{f}}}{C_{\mathrm{Cl}, \mathrm{sw}}-C_{\mathrm{Cl}, \mathrm{f}}}$

where $C_{\mathrm{Cl}, \mathrm{sam}}, C_{\mathrm{Cl}, \mathrm{f}}$, and $C_{\mathrm{Cl}, \mathrm{sw}}$ refer to the $\mathrm{Cl}$ concentration in the collected water sample, freshwater, and seawater in this area, respectively. Sample CG14, with the lowest concentration of $\mathrm{Cl}^{-}$, can be considered as representative of freshwater.

Hydrogeochemical modeling was used to quantify the effect of processes such as mixing, reactions, and evaporation using the code PHREEQC-2 (version 2.18.3, Parkhurst and Appelo, 1999). Different mode scenarios were designed on the basis of local hydrochemical conditions, and the geographic location of the point in the catchment. The potential minerals used in the geochemical models are limited to those present in the aquifers. Further details of each simulation will be discussed below.

\section{Results}

Groundwater levels ranged from $\sim 20 \mathrm{~m}$ a.s.1 in the eastern recharge area to $\sim 1 \mathrm{~m}$ a.s.l near the coastline in August 2010, with $0.9 \mathrm{~m}$ a.s.l in the central part of the Daweijia well field. Groundwater levels in the Quaternary as well as the carbonate aquifer are sensitive to the pumping activities and precipitation conditions.
The available groundwater level data monitored during intensive groundwater exploitation from 1979 to 1981 (Fig. 2a) show that groundwater levels in the carbonate aquifer fluctuated significantly between the dry (from May to June) and the wet season (July and August). For well CG1, for example, the groundwater level varied between $-9 \mathrm{~m}$ a.s.l in May 1980 and $3 \mathrm{~m}$ a.s.l in August 1979 (Fig. 2). Similar behavior is demonstrated by well CG2.

During the extended period of drought from 1978 to 1986 (Li et al., 2003), which can be identified in Fig. 3 from the decreasing trends of cumulative monthly rainfall departure from the mean (CRD, Weber and Stewart, 2004), and due to increasing water demand (Li et al., 2006), groundwater exploitation resulted in the formation of an elliptical cone of depression during the dry season around the year 1980 (Fig. 4a), with a long axis perpendicular to the coastline (Zhao, 1991). This cone of depression had disappeared in May 2005 (Fig. 4b) after the closure of the field in 2001 (Song, 2013). For well CG1, the minimum groundwater level changed from $-9 \mathrm{~m}$ a.s.l in May 1980 to $-2 \mathrm{~m}$ a.s.l in May 2006, while the maximum groundwater level in the well changed from $3 \mathrm{~m}$ a.s.l in August 1979 to $0.5 \mathrm{~m}$ a.s.l in August 2006 (Fig. 2). The annual amplitudes of groundwater level fluctuation decreased markedly from $12 \mathrm{~m}$ in 1979/1980 to $2.5 \mathrm{~m}$ in 2006. Comparison of the water level contour map from 1979/1981 (Fig. 4a) to that of 2004 (Fig. 4b) also suggests that groundwater flow has reversed from landward in summer to seaward at all times of the year.
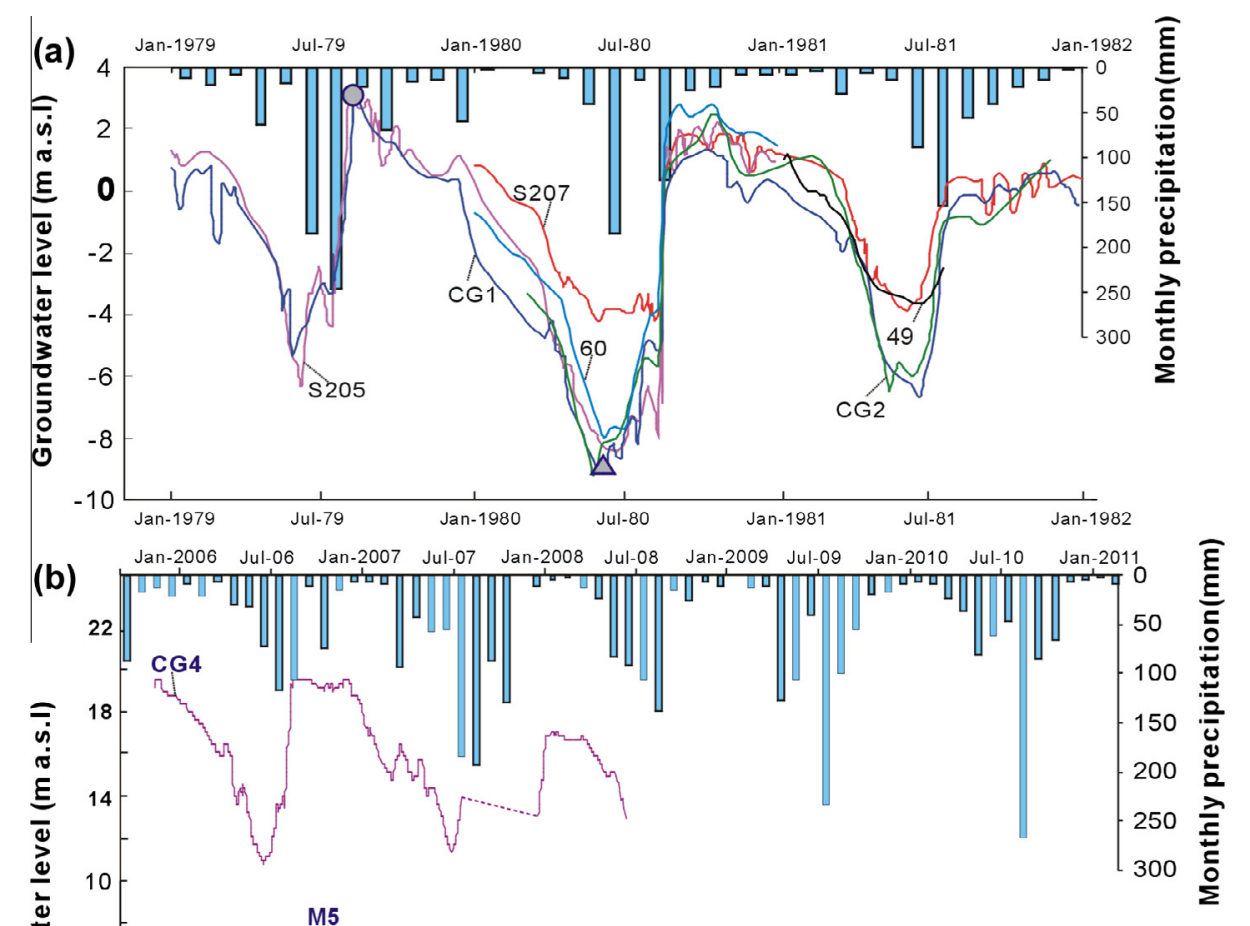

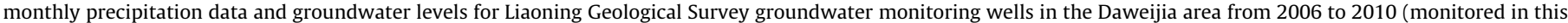

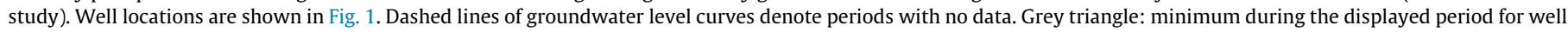
CG1; Grey circle: maximum during the displayed period for well CG1. 
The average $\mathrm{Cl}^{-}$concentration in groundwater from 8 representative monitoring wells (shown in Fig. 3) changed from $199 \mathrm{mg} / \mathrm{L}$ in 1966 , to $1137 \mathrm{mg} / \mathrm{L}$ in 1982 , to $940 \mathrm{mg} / \mathrm{L}$ in 1983 , to $560 \mathrm{mg} / \mathrm{L}$ in 1991 , to $940 \mathrm{mg} / \mathrm{L}$ in 1994 , and then decreased to $454 \mathrm{mg} / \mathrm{L}$ in 2005 (Song, 2013). The increasing salinity during the 1960s to 1970s coincided with periods of above-average rainfall (as inferred from the increasing trend in the CRD, Fig. 3). The area with a groundwater $\mathrm{Cl}^{-}$concentration of greater than $250 \mathrm{mg} / \mathrm{L}$ was $24 \mathrm{~km}^{2}$ in 1991, and $54 \mathrm{~km}^{2}$ in 2003 (Fig. 3). This area consistently grew larger from 1960 to 1995 , even though the average $\mathrm{Cl}^{-}$ concentration decreased in the 1980s. After pumping was reduced in 1995, the area shrank to values between 15 and $26 \mathrm{~km}^{2}$ (Song, 2013). A drought from 1999 to 2008, which is recognizable by the decreasing trend in CRD in Fig. 3, caused the spike in the area with $\mathrm{Cl}^{-}>250 \mathrm{mg} / \mathrm{L}$ and the increased averaged $\mathrm{Cl}^{-}$concentrations during this period.

A clear seasonal trend of $\mathrm{Cl}^{-}$concentrations has been reported for wells in the coastal zone and near the well field (Fan, 1984; Wu et al., 1994). Chloride concentrations vary inversely proportional to the water levels and there appears to be a lag time of

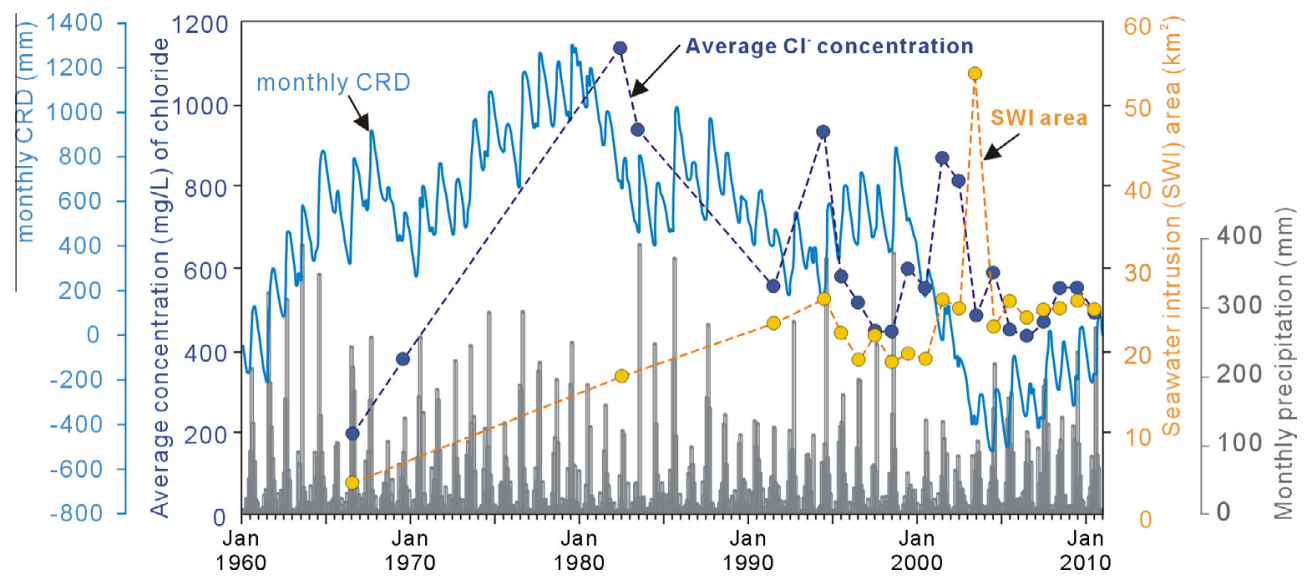

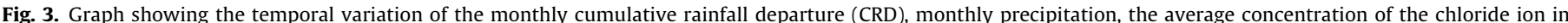

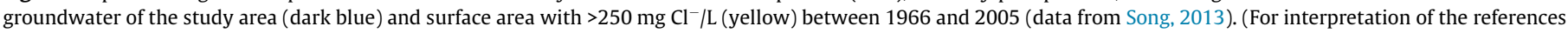
to color in this figure legend, the reader is referred to the web version of this article.)
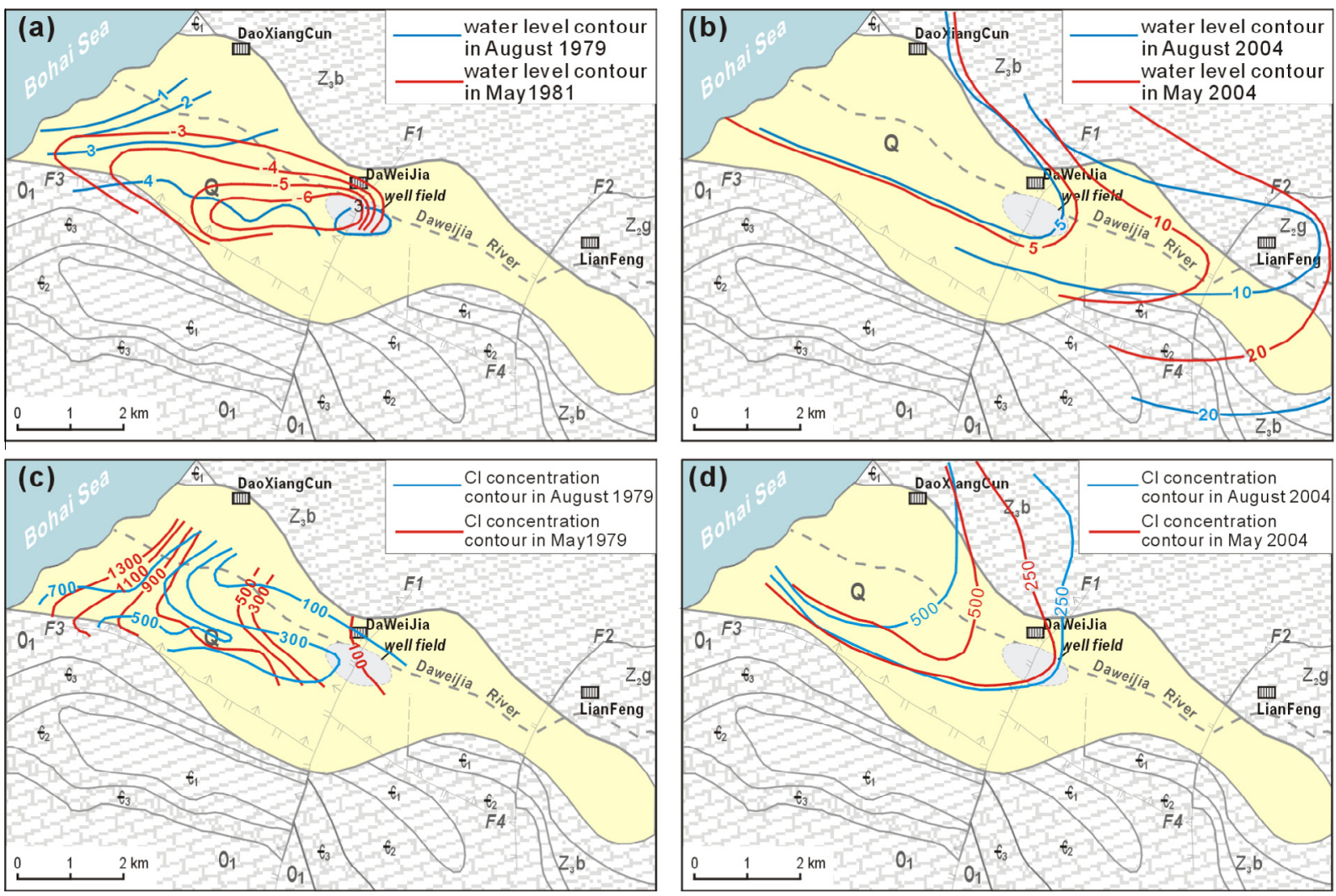

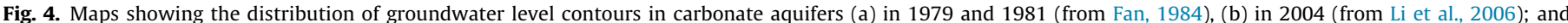

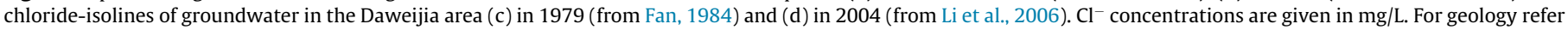
to Fig. 1. 
up to several weeks between the extremes in water level and $\mathrm{Cl}^{-}$ concentration (Supplementary Figs. S1 and S2). Salinities also appear to respond to pumping. For example, for well D5 (Supplementary Fig. S2) the interruption of abstraction in 1976 (Lü et al., 1981) was followed by a small recovery of the water level and a decrease of the $\mathrm{Cl}^{-}$concentration.

The physical and chemical characteristics of groundwater samples from the Quaternary aquifer (QA) and the Cambrian-Ordovician carbonate aquifer (COA) taken in the Daweijia in 2008-2010 are compiled in Table 2. Total dissolved solids (TDS) concentrations vary from 372 to $2137 \mathrm{mg} / \mathrm{L}$, with values increasing along the main direction of groundwater flow from the east toward the sea. The $\mathrm{NO}_{3}^{-}$concentrations of the investigated groundwater samples in this study range from 4.3 to $624.5 \mathrm{mg} / \mathrm{L}$, and most are markedly higher than the WHO (World Health Organization) standard (50 mg/L) for drinking water (WHO, 2006). All dissolved oxygen measurements showed concentrations greater than $2 \mathrm{mg} / \mathrm{L}$ so that it can be assumed that denitrification plays an insignificant role. The two seawater samples taken during this study had different $\mathrm{NO}_{3}$ concentrations, $47 \mathrm{mg} / \mathrm{L}$ and $1092 \mathrm{mg} / \mathrm{L}$, respectively. The extremely high value are much higher than the data (approximately $0.4 \mathrm{mg} / \mathrm{L}$ ) reported by Chen (2008), indicating severe localized pollution of the marine environment.

Fig. 5 shows that most of groundwater has low $\mathrm{Na} / \mathrm{Cl}$ ratios compared to seawater, and groundwater with the highest $\mathrm{Cl}^{-}$concentrations is characterized by low $\mathrm{Ca} / \mathrm{Cl}$, and $\mathrm{Mg} / \mathrm{Cl}$ ratios. There is no discernable difference between the QA and COA. These ratios of brackish groundwater are relatively low compared to fresh groundwater, reflecting the dominance of $\mathrm{Cl}^{-}$as the main anion in the former. Fig. $5 \mathrm{~d}$ shows the variation of $\mathrm{Mg} / \mathrm{Ca}$ versus $\mathrm{Cl}^{-}$concentrations. The $\mathrm{Mg} / \mathrm{Ca}$ ratios range from 0.2 to 1.3 and increase with increasing salinity.

The SI for common minerals in all water samples were calculated using PHREEQC version 2.8 (Parkhurst and Appelo, 1999). Fig. S3 (Supplementary figure) represents the relation between saturation indexes for the minerals calcite, dolomite and gypsum and the dissolved $\mathrm{SO}_{4}^{2-}$ concentration. Most groundwater samples are oversaturated or close to equilibrium with respect to calcite and dolomite. Groundwater samples are typically closer to saturation with calcite than with dolomite (Fig. S3d). Saturation indices of gypsum indicate undersaturation for all samples (Fig. S3c), and as expected the degree of undersaturation decreases with increasing $\mathrm{SO}_{4}^{2-}$ concentration, especially in the brackish groundwater.

Groundwater samples have $\delta^{18} \mathrm{O}$ values between $-11.2 \%$ and $-5.1 \%$, and $\delta^{2} \mathrm{H}$ values between $-68 \%$ and $-51 \%$ (Table 2 ). The local meteoric water line (LMWL) is given by $\delta^{2} \mathrm{H}=7.7 \delta^{18} \mathrm{O}+8.7$ $\left(r^{2}=0.92\right.$, Deng et al., 2012) based on $\delta^{18} \mathrm{O}$ and $\delta^{2} \mathrm{H}$ values of average monthly rainfall (data from IAEA/WMO, 2006) at Tianjin station $\left(39^{\circ} 05^{\prime} 09^{\prime \prime} \mathrm{N}, 117^{\circ} 11^{\prime} 47^{\prime \prime} \mathrm{E}\right)$ some $350 \mathrm{~km}$ north of Dalian city. The amount-weighted mean $\delta^{18} \mathrm{O}$ and $\delta^{2} \mathrm{H}$ values of rainfall in Tianjin station are $-7.7 \%$ and $-49 \%$, respectively. Due to similar climatic and coastal conditions, the rainfall characteristics in the coast city Tianjin are assumed representative for the study area. The linear regression lines of the groundwater samples $\left(\delta^{2} \mathrm{H}=1.86 \delta^{18} \mathrm{O}+41.58\right.$ for groundwater samples from the QA, and $\delta^{2} \mathrm{H}=1.92 \delta^{18} \mathrm{O}-42.03$ for groundwater samples from the
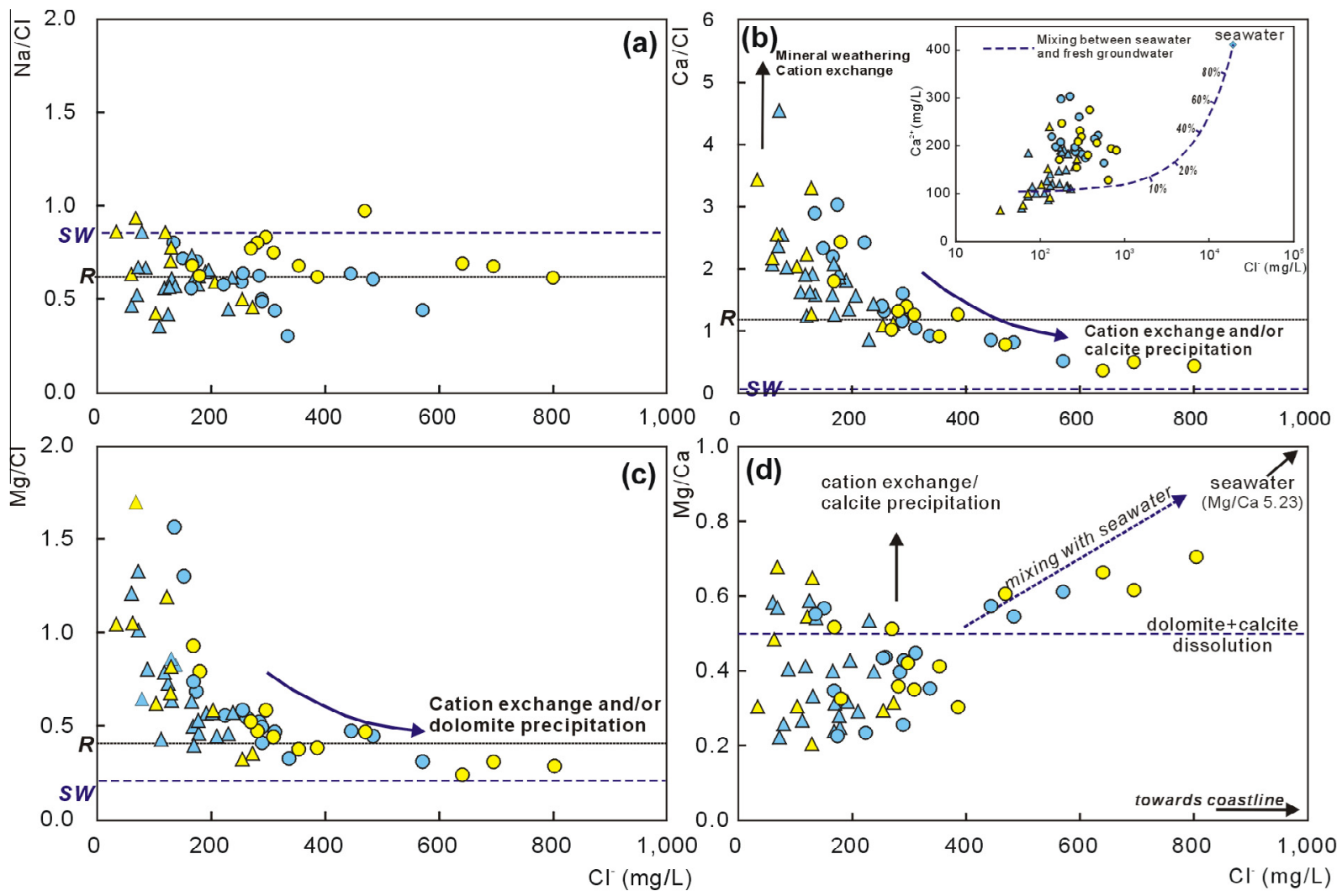

LEGEND: $\triangle$ CG-fresh OCG-brackish $\triangle$ QG-fresh $\quad$ O QG-brackish

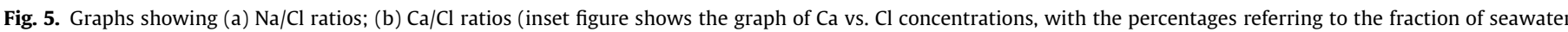

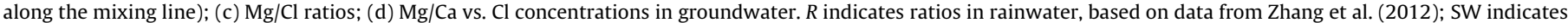

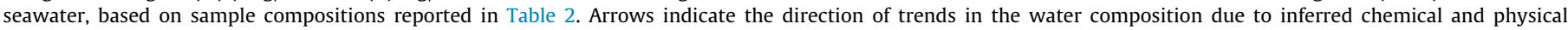
processes. 
COA, respectively) have a smaller slope than the Global Meteoric Water Line (GMWL; $\delta^{2} \mathrm{H}=8 \delta^{18} \mathrm{O}+10$; Craig, 1961) and LMWL (Fig. 6a). Along the groundwater flow path, groundwater becomes more enriched in $\delta^{18} \mathrm{O}$ in the downstream area (-6.8\%o in CG1) than the groundwater $(-8.4 \%$ in CG14) in the upstream area. The fresh and brackish groundwaters in QA and COA are characterized by a similar range in isotopic $\delta$-values. Groundwater samples collected before the rain season present more enrichment in $\delta^{18} \mathrm{O}$ and scatter in $\delta^{2} \mathrm{H}$ than those collected in the rain season (August 2009 and August 2010). Relatively depleted isotope contents (e.g. CG9 with $\delta^{18} \mathrm{O}=-10.0 \%$ in August 2010) indicate a quick response to heavy rainfall (recorded to have a $\delta^{18} \mathrm{O}=-11.2 \%$, and $\delta^{2} \mathrm{H}=-69 \%$ on 19 th August, 2010, see Table 2).

\section{Discussion}

\subsection{Seawater intrusion and reversibility}

From the observation that the salinity rise up until 1983 occurred during years with mainly above-average rainfall (Fig. 3) it is inferred that this increase was due to seawater intrusion caused by the abstraction from the well field. Conversely, the decrease of the $\mathrm{Cl}^{-}$concentration after 1983 is attributed to the reduction in pumping and change to a seasonal pumping regime. The more recent data collected during this study show that the fraction of seawater (Eq. (1)) does not exceed 5\% near the Daweijia well field. Compared with $21 \%$ in 1982 (Wu et al., 1994), the degree of SWI has been obviously reduced after the local government restricted groundwater abstraction. This is corroborated by the
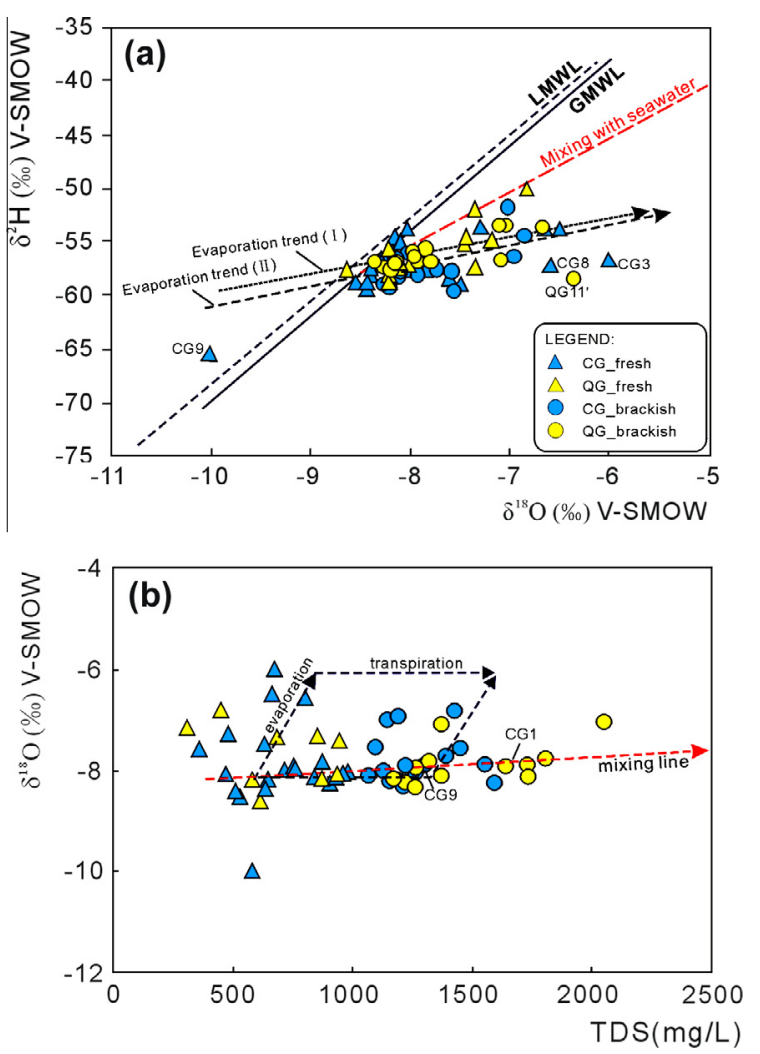

Fig. 6. Graphs showing (a) $\delta^{2} \mathrm{H}$ vs. $\delta^{18} \mathrm{O}$ of water samples in Daweijia groundwaters and (b) $\delta^{18} \mathrm{O}$ vs. TDS concentrations of groundwater. GMWL = global meteoric water line: $\delta^{2} \mathrm{H}=8 \delta^{18} \mathrm{O}+10$ (Craig, 1961); LMWL = local meteoric water line: $\delta^{2} \mathrm{H}=7.7$ $\delta^{18} \mathrm{O}+8.7$ (Deng et al., 2012). The evaporation trend I and II refer to $\delta^{2} \mathrm{H}=1.9 \delta^{18} \mathrm{O}$ +41.6 for groundwater samples from the $\mathrm{QA}$, and $\delta^{2} \mathrm{H}=1.9 \delta^{18} \mathrm{O}-42.0$ for groundwater samples from the COA, respectively. Dashed blue arrows indicate possible departures from the main trend caused by evaporation. change in flow direction that has occurred. The inland flow direction caused by the cone of depression around the well field that was observed in 1979/1981 (Fig. 4a) has been replaced by seaward flow direction (Fig. 4c).

SWI reversibility depends on three main aspects (Tsur and Zemel, 1995; Petit, 1996): (i) the extent of the salinization that occurred, (ii) groundwater recharge conditions, and (iii) aquifer characteristics (particularly the hydraulic conductivity). The seasonal dynamics of the $\mathrm{Cl}^{-}$concentrations in response to water level fluctuations (Supplementary Figs. S1 and S2) suggests SWI reversibility in the vicinity of the Daweijia well field is strongly linked to (ii) and (iii). The dual-porosity features of the carbonate aquifer could affect SWI reversibility as seawater that entered the stagnant zones of the aquifer will persists much longer than that in the more permeable parts. The sequestration of solutes into the immobile regions of the aquifer is influenced by the seasonality of the SWI process through a periodic reversal of the solute concentration gradients that drive the diffusive exchange. This impacts on the long-term (multi-year timescale) persistence of adverse effects of SWI, which will be more severe and more long-lived if extensive quantities of salt become stored in the immobile zones.

While no direct evidence for residual seawater in stagnant zones could be found during this study, it may be expected based on the nature of the carbonate aquifer that this is a factor of importance in the $\mathrm{COA}$, and measured $\mathrm{Cl}^{-}$concentrations could at least partially be attributed to diffusive exchange between zones of contrasting permeability. This assertion is supported by the fact that some wells in close proximity of each other have different chemical and isotopic characteristics. For example, well CG11, with the same depth as CG9 (100 m) and only $90 \mathrm{~m}$ horizontally from well CG9, has more enriched isotope values and a higher salinity (TDS $1.7 \mathrm{~g} / \mathrm{L}$ for CG11 vs. $0.64 \mathrm{~g} / \mathrm{L}$ for CG9).

\subsection{Groundwater salinization and chemical processes}

The brackish groundwater samples (e.g., QG2 and QG5 collected in June 2008) in the QA in the agricultural parts of the study area show a relatively high $\delta^{18} \mathrm{O}$ value $(\sim-7.0 \%)$ and elevated $\mathrm{Cl}^{-}$concentrations (up to $414 \mathrm{mg} / \mathrm{L}$ ) compared to groundwater in the recharge area, suggesting there is an influence of ET, which is likely to be linked to irrigation return flow. For wells QG2, QG5, QG6, QG9, QG10, and QG11, the water table depth is less than $2 \mathrm{~m}$ below the surface, and is thereby well within the range $(4-5 \mathrm{~m})$ of the evaporation extinction depth in north China (Han, 2007). This means that direct evaporation from the groundwater itself may occur in addition to irrigation-linked evaporation above the water table. While the groundwater in the superficial Quaternary aquifer is most susceptible to ET, the similar isotope signature of the groundwater from QA and COA indicates that mixing between water from two aquifers likely occurs, which presumably occurs along preferential flow paths in fault zones and karst conduits.

The increase in groundwater salinity does not accompany the enrichment of the heavier water isotopes that would occur during evaporation (Fig. 6b), indicating that direct evaporation plays an insignificant role in elevating groundwater salinity. Nevertheless, it may be responsible for some of the observed scatter of the data points, as indicated by the arrows in Fig. $6 \mathrm{~b}$. The trend in the graph is either due to the effects of transpiration or the complete evaporation of rain water and subsequent dissolution precipitated salts during later recharge events (Gat and Tzur, 1967; Gat, 1980). Moreover, some high $\mathrm{Cl}^{-}$concentrations in agricultural areas (e.g., $415 \mathrm{mg} / \mathrm{L}$ in QG2) may be from fertilizer utilization with $\mathrm{Cl}$ bearing materials (such as seaweed).

Alternatively, freshwater-seawater mixing could play a role for at least some of the samples, as indicated by the position of the 


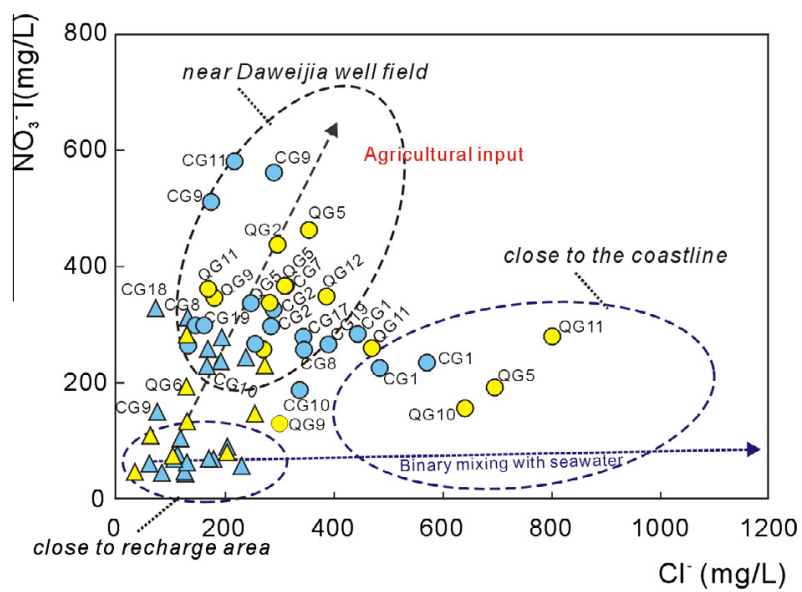

Fig. 7. Graph showing $\mathrm{NO}_{3}$ plotted vs. $\mathrm{Cl}$. See Fig. 5 for legend. Even if the extremely higher nitrate concentration in the seawater, groundwater with nitrate concentrations more than $55 \mathrm{mg} / \mathrm{L}$ (maximum 5\% seawater fraction) may be attributed to the anthropogenic pollution source (e.g., agricultural input, fish farming pollution). mixing line relative to the data points in Fig. $6 \mathrm{~b}$. This would be consistent with the previously noted possibility that residual salinity in the stagnant zones of the aquifer mixes with freshwater circulating through more permeable regions. In order to assess if the salinity is related to agricultural activities or to seawater-freshwater mixing, concentrations of $\mathrm{NO}_{3}^{-}$were plotted vs. those of $\mathrm{Cl}^{-}$ (Fig. 7). Despite the extremely high $\mathrm{NO}_{3}^{-}$concentrations, found in the seawater, and based on a maximum value of $f_{\text {sea }}=0.05$ (as inferred from the highest $\mathrm{Cl}^{-}$concentration measured), $\mathrm{NO}_{3}^{-}$concentrations $>55 \mathrm{mg} / \mathrm{L}$ must be attributed to agricultural activities. Also, given the pronounced influence of irrigation activities and in the absence of any significant denitrification, a proportional increase of $\mathrm{NO}_{3}^{-}$with $\mathrm{Cl}^{-}$would be expected, and as can be seen from Fig. 7, despite significant scatter, this appears to be the case for groundwater samples near the Daweijia well field. This makes it more likely that the elevated salinities are related to agricultural activities rather than mixing of freshwater and seawater. For samples taken closer to the coast (e.g., QG10, QG11), however, the increase of $\mathrm{NO}_{3}$ with $\mathrm{Cl}-$ is less pronounced, which would be consistent with freshwater mixing with more saline water low in $\mathrm{NO}_{3}^{-}$.

Table 3

Scenarios calculated with PHREEQC-2 (units in mol/L).

\begin{tabular}{lll}
\hline Processes & $\begin{array}{l}\text { Defined mineral } \\
\text { assemblage }\end{array}$ & $\begin{array}{l}\text { Calculated mole transfer of inverse modeling scenarios and calculated } \\
\text { results of forward modeling }\end{array}$ \\
\hline $\begin{array}{l}\text { Scenario 1 } \\
\text { Inverse modeling: }\end{array}$ & Phase mole transfers: \\
Initial solution QG3, final solution CG4 & \\
Dolomite & Dolomite \\
Gypsum & Gypsum \\
Calcite & Calcite \\
$\mathrm{CO}_{2}(\mathrm{~g})$ & $\mathrm{CO}_{2}(\mathrm{~g})$ \\
$\mathrm{CaX}_{2}$ & $\mathrm{CaX}_{2}$ \\
$\mathrm{MgX}_{2}$ & Precip & $\mathrm{MgX}_{2}$ \\
$\mathrm{NaX}$ & & $\mathrm{NaX}$
\end{tabular}

Scenario 2

Forward modeling

Initial solution: $\mathrm{Mix}(\mathrm{QG} 3+\mathrm{CG} 3)$

Mix ratio: $0.86(\mathrm{QG} 3): 0.14(\mathrm{CG} 3)$

REACTION 1 (fertilizer addition)

$\mathrm{Ca}\left(\mathrm{NO}_{3}\right)_{2} \quad 2.08 \mathrm{e}-3$

$\mathrm{H}_{2} \mathrm{O}-55.6 * 0.69$

(Evaporation: to remove 69\% of water volume)

$\mathrm{CaX}_{2}$

$\mathrm{MgX}_{2}$

$\mathrm{NaX}$

$\mathrm{KX}$

$\mathrm{CO}_{2}(\mathrm{~g})$
Take QG5 as a referenced water sample to compare Calculated results:

$\mathrm{NO}_{3}^{-}: 5.4 \mathrm{e}-03$
Observed results (August 2010): $\mathrm{NO}_{3}^{-}: 5.4 \mathrm{e}-03$

Scenario 3

Inverse modeling: initial solution: Mix (QG3 + seawater), final solution:QG11

Mixing ratios:0.045 (seawater):0.955 (QG3)

\begin{tabular}{llll} 
Dolomite & & Evaporation: & \multicolumn{1}{c}{ Remove 9/10 vol. water } \\
Calcite & Dissolve & Dolomite & $1.082 \mathrm{e}-03$ \\
$\mathrm{Halite}$ & Precip & Calcite & $-5.557 \mathrm{e}-04$ \\
$\mathrm{Gypsum}$ & & Gypsum & $1.943 \mathrm{e}-03$ \\
$\mathrm{CaX}$ & & $\mathrm{CaX}$ & $-2.395 \mathrm{e}-06$ \\
$\mathrm{NaX}$ & & $\mathrm{NaX}$ & $2.611 \mathrm{e}-05$ \\
$\mathrm{KX}$ & & $\mathrm{KX}$ & $-2.132 \mathrm{e}-03$ \\
$\mathrm{CO}_{2}(\mathrm{~g})$ & Precip & $\mathrm{CO}_{2}(\mathrm{~g})$ & $1.836 \mathrm{e}-03$
\end{tabular}

(number indicates the difference between the exchanger compositions before and after fertilizer addition/evapoconcentration)

$\begin{array}{ll}\mathrm{CaX}_{2} & 1.30 \mathrm{e}-03 \\ \mathrm{NaX} & -1.63 \mathrm{e}-03 \\ \mathrm{MgX}_{2} & -3.50 \mathrm{e}-04 \\ \mathrm{KX} & -1.10 \mathrm{e}-04\end{array}$

$\mathrm{CO}_{2}(\mathrm{~g})$

Define WATER for evaporation (variable degree)

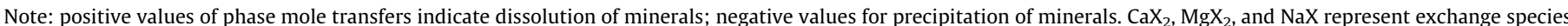
including stoichiometry of exchange ion and exchanger. 
This could be relic intruded seawater but another likely source of this saline water is the fish farms.

Some deep groundwater samples from the COA have high $\mathrm{NO}_{3}$ concentrations (e.g. $579 \mathrm{mg} / \mathrm{L}$ in CG11), indicating flow and mixing between the QA and COA. This is consistent with the similarity in the isotopic composition of the QA and COA, as noted above. The relatively low nitrate concentrations in some deep groundwater (e.g. CG4, CG3, CG14 from COA), which are located in the upstream area, show that, compared with groundwater in the downstream area, these waters have little contamination from human activities.

High major-cation/Cl- ratios (Fig. 5) in fresh groundwater with $\mathrm{Ca}-\mathrm{HCO}_{3}$ water type near the recharge area indicate that a major process that affects the solutes in that region is mineral weathering. Inverse modeling with PHREEQC using groundwater samples QG3 and CG4 as the initial and final solutions, respectively yielded a thermodynamically feasible solution when dissolution of dolomite as well as ion exchange $\left(\mathrm{Mg}^{2+}+\mathrm{Ca}-\mathrm{X}_{2} \rightarrow \mathrm{Ca}^{2+}+\mathrm{Mg}-\mathrm{X}_{2}\right)$ were considered (see Scenario 1 in Table 3 ). $\mathrm{HCO}_{3}^{-}$is the main anion that is released. The model results reflect that the elevated $\mathrm{Mg}^{2+}$ may result from the dissolution of carbonate minerals with simultaneous ion exchange.

No increasing trend in the degree of either calcite or dolomite saturation was detected with increasing $\mathrm{SO}_{4}$ concentrations, as has been described for other carbonate aquifers, such as the Edwards aquifer in Texas (Ogden and Collar, 1990) and the Alpujfirride carbonate aquifers in southern Spain (Cardenal et al., 1994). Most groundwater samples are characterized by simultaneous equilibrium with calcite and dolomite (Fig. S3), along with the under-saturation for gypsum or anhydrite. This could point to dedolomitization, which involves dolomite dissolution accompanied by calcite precipitation as a result of gypsum or anhydrite dissolution (Hanshaw and Back, 1979; Plummer et al., 1990; LópezChicano et al., 2001; Szynkiewicz et al., 2012). The dissolution of even very small amounts of gypsum may cause this process to occur in carbonate aquifers, usually characterized by near saturation in calcite (Plummer et al., 1990; López-Chicano et al., 2001; Moral et al., 2008; Szynkiewicz et al., 2012). Infiltration of meteoric waters or irrigation return flow contaminated by domestic effluents and fertilizers rich in Ca could be promoting the dedolomitization process (Pacheco and Szocs, 2006).
Irrigation water forms a source of nutrients to the groundwater. Near the Daweijia well field, a forward PHREEQC model (see Scenario 2 in Table 3 ) was developed that considers mixing of shallow fresh groundwater (QG3) with deep brackish groundwater (CG3) in a ratio of 6:1. Based on the water budget (CGS, 2009), this ratio presents the relative proportion between meteoric recharge and irrigation return flow into the aquifer. The model simulates the addition of $\mathrm{Ca}, \mathrm{NO}_{3}$ and $\mathrm{SO}_{4}$ in the form of $\mathrm{Ca}\left(\mathrm{NO}_{3}\right)_{2}$, representing fertilizer inputs. The amount of fertilizer added in the model was optimized to fit the observed values of $\mathrm{NO}_{3}$ and $\mathrm{SO}_{4}$ of groundwater sample QG5. ET of the mixture during irrigation was simulated by removing just over two-thirds of the mass of $\mathrm{H}_{2} \mathrm{O}$ until the measured $\mathrm{Cl}^{-}$concentration of sample QG5 is obtained; the saturation index for calcite was kept at the mean value of the samples in this part of the groundwater system (SIcal 0.35). Cation exchange was also simulated. The simulated concentrations of $\mathrm{NO}_{3}^{-}$in the final solution are shown in Table 3. The differences between the exchanged amounts before and after fertilizer addition/evapoconcentration (Table 3 ) indicate that dissolved Ca exchanges mainly for adsorbed $\mathrm{Na}$, with minor changes to adsorbed $\mathrm{Mg}$ and $\mathrm{K}$. The $\mathrm{MgX}_{2}$ decrease is consistent with the observed higher $\mathrm{Mg} / \mathrm{Ca}$ ratio in the shallow brackish groundwater around the well field. The decreasing $\mathrm{Na} / \mathrm{Cl}$ ratio and increasing $\mathrm{Mg} / \mathrm{Ca}$ ratio with increasing $\mathrm{Cl}^{-}$concentration may indicate longer residence times, with the ratios the $\mathrm{Cl}^{-}$concentration increasing due to internal recirculation of groundwater due to pumping/irrigation cycles, as has been observed elsewhere (Stigter et al., 1998).

Near the coast, the seawater fraction of in sample QG11' $\left(f_{\text {sea }}=0.047\right)$ has the highest value of all groundwater samples taken, which is attributed to the infiltration of seawater that is used for fish farming. An inverse model (see Scenario 3 in Table 3) was run with sample QG11 as the final solution and a 0.045:0.955 mixture of water sample QG3 and seawater as the initial solution. As the water table is within $2 \mathrm{~m}$ below ground surface evaporation was considered in this model. Different degrees (removing 1/10 and 9/10 of water, respectively) of evapoconcentration were simulated. High $\mathrm{Na} / \mathrm{Cl}$ ratios observed in the final water type are results of the release of $\mathrm{Na}^{+}$from the cation exchange complex, but the contributions of the carbonate minerals to the phase mole transfers are much higher than cation exchange (Table 3). A greater

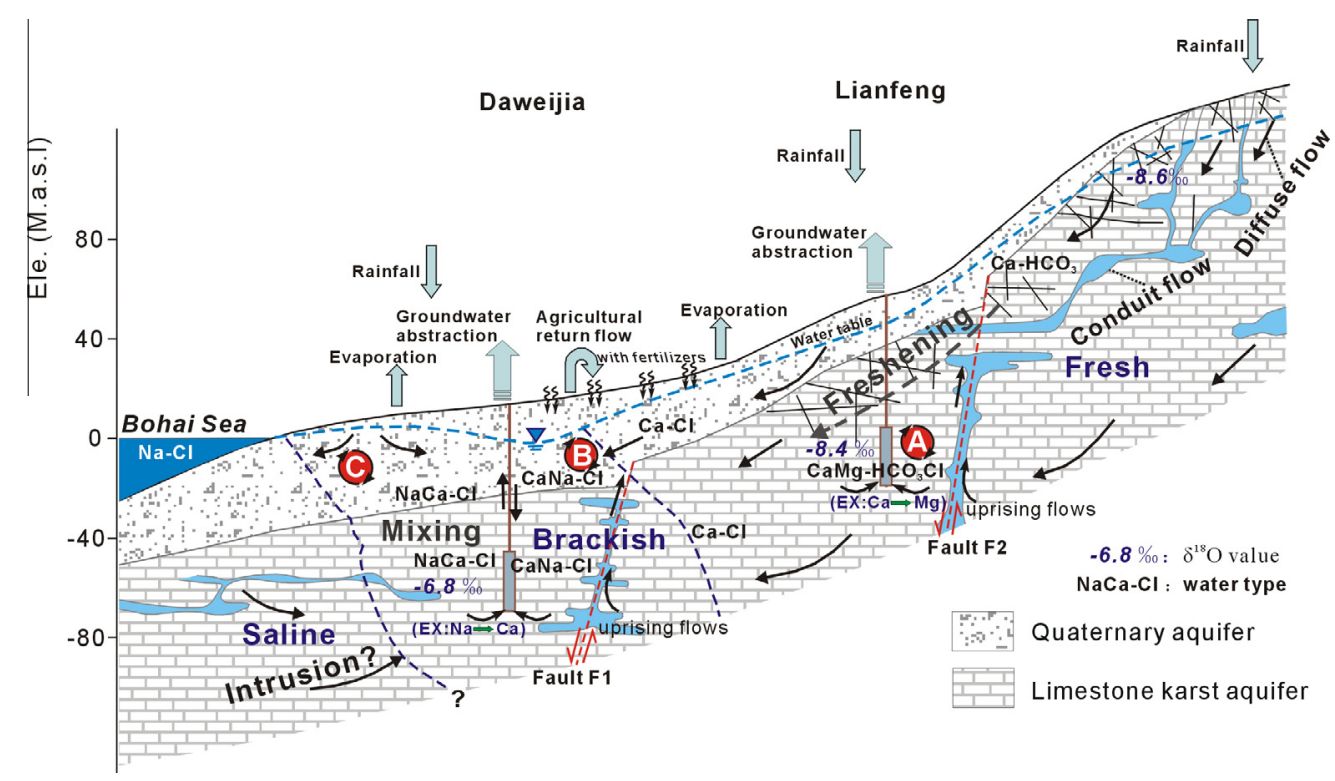

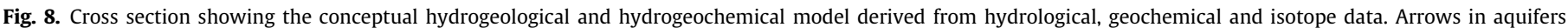

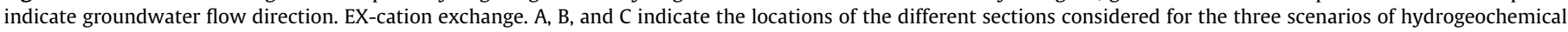
modeling. 
degree of evapoconcentration causes more calcite and dolomite dissolution, as well as an increased exchange of KX, but less exchange of $\mathrm{CaX}_{2}$. The results illustrate how large-scale fish farming in the coastal zone impacts on groundwater quality and enhance the hydrogeochemical processes.

\subsection{Conceptual model for hydrogeochemical evolution}

Combined analysis of water level data and the hydrochemical and isotopic composition in groundwater were used to develop a conceptual model of flow patterns and the processes influencing the water chemistry along a cross-section oriented from west to east (Fig. 8). The groundwater level data indicate that groundwater generally flows from west to east. Water level fluctuations and the temporal variability of $\delta^{2} \mathrm{H}-\delta^{18} \mathrm{O}$ values show that recharge is characterized by a pronounced seasonality.

In the upstream area (Lianfeng in Fig. 1 and section A in Fig. 8), shallow groundwater with depleted $\delta^{18} \mathrm{O}$ values (about $-8.6 \%$ ) flows through the conduits and into the deeper carbonate aquifer. The composition of this water is mainly controlled by carbonate dissolution and cation exchange. Shallow groundwater near the Daweijia well field is impacted by evapotranspiration (irrigation return flow) and fertilizer use (section B in Fig. 8), as demonstrated by high $\mathrm{NO}_{3}^{-}$concentrations. The similar chemical-isotopic signature of the groundwater from $\mathrm{QA}$ and $\mathrm{COA}$ and high $\mathrm{NO}_{3}^{-}$concentrations in the COA confirm that there are potential hydraulic connections between two aquifers.

In the coast zone, fish farming increases shallow groundwater salinity and cause pollution by using nitrogen fertilizer, with different degree of evapoconcentration (section C in Fig. 8). Under the intensive pumping, seawater readily migrated into the deep carbonate aquifer via preferential flow along fault zones or conduits in the carbonate aquifer.

\section{Summary and conclusions}

The coastal aquifer system in the Daweijia area is composed of Quaternary sedimentary and Cambrian-Ordovician carbonate rocks, and forms an example of an area where seawater intrusion has been reversed by closing the main well field in 2001. Since then the area affected by salinization as well as the average salinity of the groundwater have decreased, and it is not obvious if elevated salinities should be attributed to seawater mixing or other factors, such as anthropogenic activities. No conclusive evidence could be obtained from the relation between $\delta^{18} \mathrm{O}$ values and TDS concentrations. However, given that the groundwater flow direction is no longer landward but seaward, and the high $\mathrm{NO}_{3}^{-}$concentrations, it appears likely that the groundwater evolves from fresh water (meteoric recharge) to brackish water by evapo-concentration. The water quality is further influenced by a combination of natural and anthropogenic processes, including carbonate dissolution, cation exchange, and fertilizer input.

We proposed a hydrogeological conceptual model in the Daweijia area according to the analysis of hydraulic dynamics, hydrochemical and isotopic composition of groundwater system. The hydrogeochemical modelings were employed in three scenarios for quantifying the water-rock interaction during hydrogeochemical evolution, from the upstream area, to the well field, then to the coast zone. The results show that incongruent dissolution of dolomite determines the chemical composition of the less mineralized water in the upstream area. The high loads of agricultural fertilizers in irrigation return flows are most likely to be the main source of the dissolved nitrate in Quaternary groundwater. Fish farming using seawater is responsible for the degradation of shallow groundwater quality in the coastal zone.
The historical monitored groundwater level and $\mathrm{Cl}^{-}$concentrations of the representative wells show that there has been a reversal of SWI, similar to what has been in carbonate aquifers elsewhere (Dunn, 2000; Giordana and Montginoul, 2006). This study is the first to document this phenomenon occurs in the coastal area of China. The slow release by diffusion of dissolved salts stored during SWI in immobile regions can make that salinities above pre-SWI levels will persist after the seawater has been flushed from the permeable parts of the aquifer. Due to the nature of the data and uncertainty about the distribution of mobile and immobile regions, no quantitative assessment of this process could be made, but it appears likely that the elevated salinities result from this process to at least some part. Given the paucity of studies in the literature on the reversal of SWI, there is scope for more work, in particular investigations of different aquifer types and assessments of the temporal variability across seasonal to multiyear timescales.

\section{Acknowledgements}

This research was made through the financial support of the strategic science and technology project of the Exploring Advanced Discipline (No. 2012QY007) in the Institute of Geographic Sciences and Natural Resources Research, Chinese Academy of Sciences, and was undertaken as part of a groundwater survey project entitled "Assessment of Vulnerability and Investigation of Environmental Geology in the Key Section of Circum-Bohai-Sea Region". The authors appreciate the helpful field work and data collection made by Dr. Xie Hailan and Pan Tong from Tianjin Institute of Geology and Mineral Resources and Liaoning Survey Academy of Geology and Mineral Resources, Dr. Wang Peng, and Dr Liu Xin from Chinese Academy of Sciences.

\section{Appendix A}

See Table 2 .

\section{Appendix B. Supplementary material}

Supplementary data associated with this article can be found, in the online version, at http://dx.doi.org/10.1016/j.jhydrol.2015.11. 013.

\section{References}

Appelo, C.A.J., Postma, D., 2005. Geochemistry, Groundwater and Pollution, second ed. A.A. Balkema Publishers, Leiden, The Netherlands.

Back, W., Hanshaw, B.B., Pyle, T.E., Plummer, L.N., Weidie, A.E., 1979. Geochemical Significance of Groundwater Discharge and Carbonate Solution of the Formation of Caleta Xel Ha, Quintana Roo, Mexico.

Bicalho, C.C., Batiot-Guilhe, C., Seidel, J.L. Van Exter, S., Jourde, H., 2012. Geochemical evidence of water source characterization and hydrodynamic responses in a karst aquifer. J. Hydrol. 450-451, 206-218.

Biondić, B., Biondić, R., Kapelj, S., 2006. Karst groundwater protection in the Kupa River catchment area and sustainable development. Environ. Geol. 49, 828-839.

Bouchaou, L., Michelot, J.L., Vengosh, A., Hsissou, Y., Qurtobi, M., Gaye, C.B., Bullen, T. D., Zuppi, G.M., 2008. Application of multiple isotopic and geochemical tracers for investigation of recharge, salinization, and residence time of water in the Souss-Massa aquifer, southwest of Morocco. J. Hydrol. 352, 267-287.

Cardenal, J., Benavente, J., Cruz-Sanjulián, J.J., 1994. Chemical evolution of groundwater in Triassic gypsum-bearing carbonate aquifer (Las Alpujarras, southern Spain). J. Hydrol. 161, 3-30.

CGS (Chinese Geology Survey), 2009. Report of the Development and Utilization of Water Resources in the Coastal Zone of Liaoning Province (2005-2008) Geological survey institute of Liaoning Province, pp. 37-44.

Chen, C.T.A., 2008. Distributions of nutrients in the East China Sea and the South China Sea connection. J. Oceanogr. 64, 737-751.

Cita, M.B., Ryan, W.B.F., 1978. Messinien erosional surfaces in the Mediterranean. Mar. Geol. 27, 193-366.

Craig, H., 1961. Standard for reporting concentration of deuterium and oxygen-18 in natural water. Science 133, 1833-1834. 
Daniele, L., Vallejos, Á., Corbella, M., Luis, Molina L., Pulido-Bosch, A., 2013. Hydrogeochemistry and geochemical simulations to assess water-rock interactions in complex carbonate aquifers: the case of Aguadulce (SE Spain). Appl. Geochem. 29, 43-54.

Deng, W.P., Yu, X.X., Jia, G.D., 2012. Sources and stable isotope characteristics of precipitation in North China. Bull. Mineral. Petrol. Geochem. 31 (5), 489-494 (in Chinese with English abstract).

Drew, D.P., 1999. Karst water and human activities: an overview. In: Drew, D.P. Hôtzl, H. (Eds.), Karst Hydrogeology and Human Activities. Impacts, Consequences and Implications, I.A.H., International Contributions to Hydrogeology, vol. 20. A.A. Balkema, Rotterdam, The Netherlands, pp. 3-12.

Dunn, D., 2000. Three-dimensional Analysis of Saltwater Intrusion City of Pompano Beach area Broward County, Florida. Department of Planning and Environmental Protection. Technical Report Series (TR: 2000-00), April 2000.

Edmunds, W.M., 1996. Bromine geochemistry of British groundwaters. Mineral Mag. 60, 275-284.

El Yaouti, F., El Mandour, A., Khattach, D., Benavente, J., Kaufmann, O., 2009 Salinization processes in the unconfined aquifer of Bou-Areg (NE Morocco): a geostatistical, geochemical, and tomographic study. Appl. Geochem. 24, 16-31.

Escolero, O.A., Marin, L.E., Domínguez-Mariani, E., Torres-Onofre, s., 2007. Dynamic of the freshwater-saltwater interface in a karstic aquifer under extraordinary recharge action: the Merida Yucatan case study. Environ. Geol. 51, 719-723.

Fan, J.J., 1984. Seawater intrusion and calculation of groundwater exploitation in the karst area of the west JinXian, Dalian. Hydrogeol. Eng. Geol. 1, 3-6 (in Chinese with English abstract).

Fetter, C.W., 1994. Applied Hydrogeology. Prentice Hall, Englewood Cliffs.

Fidelibus, M.D., Gim_enez, E., Morell, I., Tulipano, L., 1993. Salinization processes in the castellon plain aquifer (Spain). In: Custodio, E., Galofr_e, A. (Eds.), Study and Modelling of Saltwater Intrusion into Aquifers. Centro Internacional de Métodos Numéricos en Ingeniería, Barcelona, pp. 267-283.

Fidelibus, M.D., Tulipano, L., 1991. Mixing phenomena owing to sea water intrusion for the interpretation of chemical and isotopic data of discharge waters in the Apulian coastal carbonate aquifer (southern Italy). In: De Breuck, C. (Ed.), Hydrology of Salt Water Intrusion: A Selection of SWIM Papers, vol. 11. IAH, Germany, pp. 317-327.

Fleury, P., Bakalowicz, M., de Marsily, G., 2007. Submarine springs and coastal karst aquifers: a review. J. Hydrol. 339, 79-92.

Gat, J.R., 1980. The relationship between surface and subsurface waters: water quality aspects in areas of low precipitation/Rapport entre les eaux de surface et les eaux souterraines: aspects des propriétés caractéristiques de l'eau dans les zones à précipitation faible. Hydrol. Sci. Bull. 25 (3), 257-267. http://dx.doi.org 10.1080/02626668009491933.

Gat, J.R., Tzur, Y., 1967. Modification of the isotopic composition of rainwater by processes which occur before groundwater recharge. In: Isotope Hydrology, Proc. Symp. Vienna 1966, IAEA, Vienna, pp. 49-60.

Giordana, G.A., Montginoul, M., 2006. Policy instruments to fight against seawater intrusion in coastal aquifers: an overview. Vie et Milieu - Life Environ. 56 (4), 287-294.

Han, D.M., 2007. Groundwater Flow Systems and Modelling of Hydrogeochemical Evolution in Quaternary Formation in Xinzhou Basin, North China. Ph.D. Thesis, China University of Geosciences, Wuhan, China.

Hanshaw, B.B., Back, W., 1979. Major geochemical processes in the evolution of carbonate-aquifer systems. J. Hydrol. 43 (1-4), 287-312.

Hanshaw, B.B., Back, W., 1985. Deciphering hydrological systems by means of geochemical processes. Hydrol. Sci. J./J. Sci. Hydrol. 30, 257-271.

IAEA/WMO, 2006. Global Network of Isotopes in Precipitation. The GNIP Database Vienna. <http://www-naweb.iaea.org/napc/ih/IHS_resources_gnip.html> (Cited September 2010)

Jin, Y.J., Wu, Q., 1990. The application of the electrical logging of well fluid in determining the vertical heterogeneity of sea water intrusion. J. Heibei College Geol. 13 (1), 69-73 (in Chinese with English abstract).

Kafri, U., Goldman, M., Lyakhovsky, V., Scholl, C., Helwig, S., Tezkan, B., 2007. The configuration of the fresh-saline groundwater interface within the regional Judea Group carbonate aquifer in northern Israel between the Mediterranean and the Dead Sea base levels as delineated by deep geoelectromagnetic soundings. J. Hydrol. 344, 123-134.

Li, W.J., Zhao, Z.G., Li, X., Sun, L.H., 2003. Drought characteristics analysis in North China and its causes of formation. Arid Meteorol. 21 (4), 1-5 (in Chinese with English abstract)

Li, Z.G., 2004. Current Status of Seawater Intrusion and Prevention Measures in Dalian City. Master's degree Thesis, Hohai University (Nanjing, China), pp. 1720 (in Chinese with English abstract).

Liu, C.L., Liu, S.L., 2001. Maricultural development situations and sustainable development problems in China. J. Oceanogr. HuangHai BoHai Seas 19 (3), 100 105 (in Chinese).

Liu, Z.M., Sha, G.Z., Wang, N.F., 1982. Report on Regional Hydrogeological Investigation of Dalian (1:200000). The Second Institute of Hydrogeology and Engineering Geology, Liaoning Bureau of Geology, pp. 54-103 (in Chinese).

Li, B.L., Yan, B.Y., Song, Q.C., Zhu, S., Gong, J.W., 2006. Report of Seawater intrusion in the Daweijia area (2004-2005). Liaoning Survey Academy of Geology and Mineral Resources. Shenyang in Liaoning Province, China, pp. 12-18.

López-Chicano, M. Bouamama, M., Vallejos, A., Pulido-Bosch, A., 2001. Factors which determine the hydrogeochemical behavior of karst springs. A case study from the Betic Cordilleras, Spain. Appl. Geochem. 16, 1179-1192.

Lü, G., Zhao, L.B., Sun, X.Z., Tan, D.F., 1981. Periodic Summary Report on Investigating the Environmental Hydrogeology in Dalian Area. The Second
Institute of hydrogeology and engineering geology, Liaoning Bureau of Geology, pp. 48-66 (in Chinese).

Magaritz, M., Nadler, A., Kafri, U., Arad, A., 1984. Hydrogeochemistry of continental brackish waters in the southern coastal plain, Israel. Chem. Geol. 42, 159-176.

Martinez-Santos, P., Martinez-Alfaro, P., Murillo, J.M., 2005. A method to estimate the artificial recharge capacity of the Crestatx aquifer (Majorca, Spain). Environ. Geol. 47, 1155-1161.

Moral, F., Cruz-Sanjulian, J.J., Olias, M., 2008. Geochemical evolution of groundwater in the carbonate aquifers of Sierra de Segura (Betic Cordillera, southern Spain). J. Hydrol. 360, 281-296.

Nadler, A., 1980. Chemical reactions of sea water with rocks and freshwater: experimental and field observations on brackish waters in Israel. Geochim. Cosmochim. Acta 44 (6), 879-886.

Ogden, A.E., Collar, P.D., 1990. Interpreting calcite, dolomite, and gypsum saturation conditions in the Edwards aquifer, Texas. In: Simpson, E.S., Sharp, J.M., Jr. (Eds.), Selected Papers on Hydrogeology from the 28th International Geologic Congress, vol. 1. International Association of Hydrogeologists, Heise, Hannover, Germany, pp. 83-96.

Pacheco, F.A.L., Szocs, T., 2006. "Dedolomitization reactions" driven by anthropogenic activity on loessy sediments, SW Hungary. Appl. Geochem. 21, 614-631.

Panagopoulos, G., 2008. Application of major and trace elements as well as boron isotopes for tracing hydrochemical processes: the case of Trifilia coastal karst aquifer, Greece. Environ. Geol. http://dx.doi.org/10.1007/s00254-008-1586-4.

Parkhurst, D.L., Appelo, C.A.J., 1999. User's Guide to PHREEQC-A Computer Program for Speciation, Reaction-Path, 1D-Transport, and Inverse Geochemical Calculation. US Geol. Surv. Water-Resour. Invest. Rep. 99-4259.

Petit, V., 1996. Les aquifères littoraux de France métropolitaine, Orléans. BRGM report, 119p.

Plummer, L.N., 1977. Defining reactions and mass transfer in part of the Floridan aquifer. Water Resour. Res. 13 (5), 801-802.

Plummer, L.N., Busby, J.F., Lee, R.W., Hanshaw, B.B., 1990. Geochemical modeling in the Madison aquifer in parts of Montana, Wyoming and South Dakota. Water Resour. Res. 26, 1981-2014.

Renken, R.A., Ward, W.C., Gill, I.P., Gomez-gomez, F., Rodriguez-martinez, J., 2002. Geology and hydrogeology of the Caribbean Islands Aquifer System of the Commonwealth of Puerto Rico and the U.S. Virgin Islands. U.S. Geological Survey Professional Paper 1419, pp. 97-124.

Sanford, W.E., Konikow, L., 1989. Simulation of calcite dissolution and porosity changes in saltwater mixing zones in coastal aquifers. Water Resour. Res. 25 (4), 655-667.

Scott, T.M., Means, G.H., Means, R.C., Meegan, R.P., 2002. First magnitude springs of Florida. Florida Geological Survey Open File Report No. 85, pp. 138.

Song, Q.C., 2013. Status quo of seawater intrusion in Daweijia karst water source of Dalian, China. J. Chengdu Univ. of Technol. (Sci. Technol. Ed.) 40 (3), 348-352 (in Chinese with English abstract).

Stigter, T.Y., van Ooijen, S.P.J., Post, V.E.A., Appelo, C.A.J., Carvalho Dill, A.M.M., 1998. A hydrogeological and hydrochemical explanation of the groundwater composition under irrigated land in a Mediterranean environment, Algarve, Portugal. J. Hydrol. 208, 262-279.

Stuyfzand, P.J., 2008. Base exchange indices as indicators of salinization or freshening of (coastal) aquifers. In: Proceedings of the 20th Salt Water Intrusion Meeting, Naples, FL, June 23-27, 2008; Program and Proceedings Book, pp. 262-265.

Sun, J., Yang, D.L., 2011. Study on sustainable development of sea aquaculture in China. J. Shanxi Agr. Sci. 39 (7), 733-735, 746.

Sun, J.F., Shen, T.E., 2010. Countermeasures for development of Dalian seawater breeding industry. J. Dalian Marit. Univ, (Soc. Sci. Ed.) 9 (2) 22-25.

Szynkiewicz, A., Newton, B.T., Timmons, S.S., Borrok, D.M., 2012. The sources and budget for dissolved sulfate in a fractured carbonate aquifer, southern Sacramento Mountains, New Mexico, USA. Appl. Geochem. 27, 1451-1462.

Tsur, Y., Zemel, A., 1995. Uncertainty and irreversibility in groundwater resource management. J. Environ. Econom. Manage. 19, 149-161.

Vengosh, A., Rosenthal, E., 1994. Saline groundwater in Israel: its bearing on the water crisis in the country. J. Hydrol. 156, 389-430.

Vengosh, A., Spivack, A.J., Artzi, Y., Ayalon, A., 1999. Geochemical and Boron, Strontium, and Oxygen Isotopic Constraints on the Origin of the Salinity in Groundwater from the Mediterranean Coast of Israel, 35(6), 1877-1894.

Weber, K., Stewart, M., 2004. A critical analysis of the cumulative rainfall departure concept. Ground Water 42 (6), 935-938.

White, W.B., 2003. Conceptual models for karstic aquifers. Speleogenesis and Evolution of Karst Aquifers, vol. 1(1), pp. 1-6.

WHO, 2006. Guidelines for Drinking-Water Quality. Recommendations, third ed., vol. 1. World Health Organization, Geneva.

Wigley, T.M.L., Plummer, L.N., 1976. Mixing of carbonate waters. Geochim. Cosmochim. Acta 40, 989-995.

Wu, Q., Jin, Y.J., 1990. Characteristics of seawater intrusion in coastal karst groundwater system of Daweijia area, Dalian City. Geotech. Invest. Surv. 3, 43-44 (in Chinese with English abstract).

Wu, Q., Jin, Y.J., Li, D.A., Xia, Y.H., 1994. The mechanisms of seawater intrusion of karst groundwater system in Daweijia, Dalian City and the countermeasures of its control. Chin. J. Geol. Hazard Control 1, 64-68 (in Chinese with English abstract).

Yang, J.L., 2011. Hydrogeochemical Reactions in Seawater Intrusion Process in Daweijia Water Source Area, Dalian City. Master's Degree Thesis, Jilin University (Changchun, China), pp. 14-15 (in Chinese with English abstract). 
Zhao, T.S., 1991. Problems of karst groundwater development in littoral area and its ultimate control method. Chin. J. Geol. Hazard Control 4, 73-77 (in Chinese with English abstract).

Zou, S.Z., Chen, H.H., Zhu, Y.F., Liu, F., 2001. Experimental study of dissolution behaviors in the fresh-saltwater transition zone of the coastal karst area. Hydrogeol. Eng. Geol. 5, 17-20 (in Chinese with English abstract).
Zou, S.Z., Zhu, Y.F., Chen, H.H., Wang, C.K., 2004. Chemical process of seawater intrusion in littoral karst area of Daweijia, Dalian City. Mar. Geol. Quatern. Geol. 24 (1), 61-68 (in Chinese with English abstract). 